\title{
ECONOMICS
}

\section{ALLOWANCE TRADING AND ENERGY CONSUMPTION UNDER A PERSONAL CARBON TRADING SCHEME: A DYNAMIC PROGRAMMING APPROACH}

\author{
by
}

Jin Fan

School of Management, University of Science and Technology of China

\section{Yao Li}

School of Management, University of Science and Technology of China

\author{
Yanrui Wu \\ Business School \\ University of Western Australia
}

Shanyong Wang

School of Management, University of Science and Technology of China

\section{Dingtao Zhao}

School of Management, University of Science and Technology of China 


\title{
ALLOWANCE TRADING AND ENERGY CONSUMPTION UNDER A PERSONAL CARBON TRADING SCHEME: A DYNAMIC PROGRAMMING APPROACH
}

\author{
Jin Fan ${ }^{\mathrm{a}}$, Yao $\mathrm{Li}^{\mathrm{a} *}$, Yanrui Wu ${ }^{\mathrm{b}}$, Shanyong Wang ${ }^{\mathrm{a}}$, Dingtao Zhao ${ }^{\mathrm{a}}$ \\ a School of Management, University of Science and Technology of China, P.R. China \\ ${ }^{\mathbf{b}}$ Business School, University of Western Australia, Australia
}

DISCUSSION PAPER 15.19

Forthcoming in Journal of Cleaner Production (JIF: 3.844)

\footnotetext{
* The corresponding author: Tel.: +86-551-63600261; Fax: +86-551-63600261.

E-mail: yaoye@mail.ustc.edu.cn (Yao Li)
} 


\begin{abstract}
:
In response to the challenge of climate change, personal carbon trading was put forward as a policy instrument to promote low carbon behavior in the household sector. To evaluate the effectiveness of this scheme, it is important to gain insight into the allowance trading and energy consumption behavior in a long emission commitment period. This paper proposes a dynamic programming model to investigate allowance trading and energy consumption. A main feature of the model is its consideration of allowance banking and borrowing activities. Ten simulated scenarios with different allowance prices, price volatility and carbon emission rates are discussed. The findings show that consumers would trade more actively when allowance price is volatile. It is also found that energy consumption and allowance trading will decrease when the carbon emission rate increases. Overall the analysis in this paper implies that personal carbon trading scheme would be an effective policy measure to change consumers' behavior. Therefore it would be valuable for decision-makers to consider the introduction and implementation of this scheme.
\end{abstract}

Keywords: Personal carbon trading; Energy consumption; Allowance price; Dynamic programming 


\section{Introduction}

Global carbon emission is increasing rapidly. If this trend continues, it will bring about disastrous climate changes. As the world's largest $\mathrm{CO}_{2}$ emitter, China is facing great pressure to reduce its carbon emissions. Current efforts to reduce carbon emissions largely rely upon promoting energy efficiency and renewable energy consumption in upstream production sectors (Brauneis et al., 2013). For instance the Chinese government shut down many carbon-intensive assembly lines and launched subsidy programs for renewable energy production and consumption (Yuan et al., 2011). Some climate exchanges such as the Tianjin Climate Exchange and Beijing Environmental Exchange have been established as market-based mechanisms to curb carbon emissions.

However these initiatives have not delivered the scale of carbon reduction as required (Seyfang, 2007). Improving energy efficiency lowers the implicit price of energy and thus may lead to greater use. This phenomenon is termed the "rebound" effect in the literature (Herring, 2006). As a result the carbon abatement effect of improving energy-efficiency has been offset by the increase of household energy consumption (Lenzen and Murray, 2001). Therefore sustainable development can only be achieved by radical changes of lifestyle and residential consumption behavior (Rood et al., 2003; Fan et al., 2012). In China the household sector is currently the second-largest energy consumer, accounting for $11 \%$ of total energy consumption in 2012, and just trailing the industrial sector (National Bureau of Statistics of China, 2014). If some measures are taken to change the consumption patterns and improve energy use efficiency, the household sector could achieve the aim of approximately $28 \%$ carbon reduction by 2020 (Murata et al., 2008). Thus, to engage consumers and households directly, new policies are needed so as to induce behavioral changes and establish sustainable lifestyles (Nissinen et al., 2014).

Personal carbon trading (PCT) could be an effective way to achieve sustained reductions at the household level by using carbon rationing and allowance trading. It would be a downstream extension of the "cap and trade” emissions trading scheme, and hence could result in widespread behavioral changes in reducing carbon 
footprints (Harwatt et al., 2011). The PCT scheme allocates consumers free emission allowances which would be reduced over time (Harwatt et al., 2011). Under-emitters with carbon emissions less than the allowance allocation could sell their surplus allowances for profit. Over-emitters who emit more than their allowance allocation have to buy additional allowances (Cohen, 2011). The technologies needed for the implementation of a PCT scheme, such as personal electronic cards, banking system and so on, are already available now. These would lay the bedrock for the social acceptability of PCT.

The effect of a PCT scheme on consumers' energy consumption behavior has attracted a lot of attention in the literature (Capstick and Lewis, 2010). Some authors argued that the PCT scheme would make consumers more aware of their personal emissions and help them to be engaged in emission reduction and to share a wider common purpose (Fleming, 2005; Starkey and Anderson, 2005). Others suggest that the PCT scheme would promote carbon budgeting (Capstick and Lewis, 2008; Howell, 2012). The PCT mechanism would lead to consumers' conservation of their carbon allowances and thus a reduction in carbon-related consumption (Parag and Strickland, 2009). Most of the existing studies are exploratory and logically inferred. Recently several empirical studies investigated the effect of the PCT scheme on consumers' behavior. Capstick and Lewis (2010) used computer-based simulations to examine the effects of consumers' decisions on their allowance trading and energy consumption behavior. Harwatt et al. (2011) used bespoke software to record consumers' behavioral responses and found that the PCT scheme would achieve behavioral changes in energy consumption.

However mathematical modelling of the PCT scheme is limited. Li et al. (2014), Fan et al. (2015a, b) constructed the optimization models of the PCT scheme to investigate consumers' energy-use choice and allowance trading behavior. These studies however ignored allowance banking and borrowing activities which could smooth the marginal abatement cost across years (Parsons et al., 2009). According to Raux (2010), the PCT scheme is a part of a wider instrument, namely transferable permits. Consumers are allowed to transfer these permit quotas between activities, 
products or places (offsetting), periods of time (banking) or to others (Godard, 2001). It is argued that intra-phase banking and borrowing is able to stabilize the allowance price level in the upstream emission trading system (Carmona et al., 2010). The present study attempts to fill the gap in the PCT literature and investigate the consumers' sequential behavior in energy consumption and allowance trading by taking inter-stage banking and borrowing into consideration. Specifically, stable and volatile allowance price scenarios are simulated to analyze their influences on consumers’ decision-making.

The rest of the paper begins with a review of the related literature. Subsequently a dynamic programming (DP) model of the PCT scheme is proposed. Then the simulations are conducted to investigate consumers' energy consumption and allowance trading behavior under different scenarios of allowance prices or emission rates and the results are discussed. The final section concludes the study and provides policy implications and recommendations for future research.

\section{Literature review}

The PCT scheme, a radical idea, was developed and promoted by two independent researchers in the mid-1990s (Fleming, 1997; Hillman, 1998). Academic passion for PCT has since never faded. Researchers have investigated the equity, public acceptability, distributional effects, and behavior changes associated with this scheme. For instance, Wallace et al. (2010) investigated public attitudes toward a PCT scheme and found that support outweighs opposition. Wadud et al. (2008) conducted an equity analysis of a PCT scheme for road transportation sector and concluded that, overall, the PCT scheme is progressive among consumers on an equal allocation basis.

Several authors analyzed the influence of PCT on consumers' energy consumption behavior. Roberts and Thumim (2006) suggested that PCT could bring about behavioral changes in energy consumption at the individual and household level. Capstick and Lewis (2008) indicated that consumers' energy-related consumption behaviors are influenced through heightened recognition of consequences and the 
accentuation of energy consciousness. Wallace (2009) used face-face interviews and the postal survey method to examine the consumers' behavioral responses to the PCT scheme and reached a conclusion that several low-carbon behaviors are favored by households. Zanni et al. (2013) conducted an experimental survey to explore individual behavioral responses to PCT in contrast with a carbon tax and showed that a PCT scheme would affect personal transport and domestic energy choices. Raux et al. (2015) used a stated preference survey and argued that a PCT scheme would effectively change consumers' travel behavior. Most of these studies provide the evidence of the effectiveness of the PCT scheme empirically or in an exploratory way from a psychological perspective.

Given the novelty of the PCT scheme, only a few researches have begun to model and investigate consumers' behavioral changes from an economic perspective. $\mathrm{Li}$ et al. (2014) proposed an equilibrium model for the PCT and investigated consumers' welfare change. Fan et al. (2015a) extended this equilibrium model to analyze consumers' energy-choice consumption and allowance trading which are subjected to the influence by factors such as allowance allocation and carbon emission rate. In another study, Fan et al. (2015b) employed an optimization model to investigate the consumers' energy demand and concluded that the PCT scheme is capable of providing certainty in carbon abatement. However these studies model the PCT scheme from a static view and ignore the fact that allowances could be transferred from one period to another (Parsons et al., 2009).

Furthermore allowance price, its volatility and carbon emission rates should be considered in consumers' decision processes. Price volatility has significant influences on consumers' trading behavior (Bessembinder and Seguin, 1992). Fawcett (2010) suggested that in a PCT scheme an equilibrium allowance price would emerge and that higher carbon lifestyles would cost more. McNamara and Caulfield (2013) examined the impact of different allowance prices under a PCT scheme in the field of the transport sector and found that consumers with sustainable lifestyles would benefit more from the higher allowance price. These studies indicated that the allowance price would provide signals and incentives for consumers' lifestyle transition. Li et al. 
(2014) and Fan et al. (2015a) developed optimization models and investigated how the allowance price is determined and how it would influence consumers' energy consumption and allowance trading. These studies assume that equilibrium allowance price is endogenous in the long run. The present research is complementary to the existing studies by assuming that the consumer is a price-taker in the short run.

The carbon emission rate is another factor which influences the decision-making of firms and consumers under the constraints of carbon emission. Fan et al (2015a) found that allowance trading volume would be susceptible to the changes in the emission rate. When the emission rate decreases, the equilibrium allowance price would decrease and the allowance trading volume would increase. Fan et al (2015a) however mainly considered the influence of the emission rate on the total allowance trading volume in the thick market. The present research attempts to further investigate the influence of emission rate on consumers' energy consumption. It adopts the DP approach to investigate the consumers' decision-making process for energy consumption and allowance trading by taking into consideration of "banking and borrowing” (Parsons et al., 2009). DP is an efficient technique for solving optimization problems with sequential decisions (Gosavi, 2015). It has been widely used in the literature on firms' or consumers’ decision making (Ilic et al., 2014; Zhu et al., 2014; Pringles et al., 2015). The method applied here is similar to that used in several previous contributions dealing with low-carbon investment decision-making (Bistline and Weyant, 2013; Wang et al., 2014).

\section{Dynamic programming model}

In this section, a DP model is proposed to investigate consumers’ decisions about allowance trading and energy consumption under a PCT scheme. The consumers are subjected to energy budget and carbon allowance constraints over an emission commitment period. The PCT scheme would involve allocating limited allowances $A_{t}$ to each consumer at the beginning of each stage $t(t=1,2,3 \ldots \mathrm{T})$ across this emission commitment period. The allowance allocation reflects the national emission 
cap, which should fall over time in order to comply with the national agreements (Fawcett, 2010). Let $A\left(A=\left[A_{1} A_{2} A_{3} \ldots A_{t-1} A_{t}\right]\right)$ denote the allowance allocation vector and the elements in $A$ be subjected to the condition: $A_{1}>A_{2}>\ldots>A_{t-1}>A_{t}$.

When a consumer's energy consumption is $y_{t}$, the consumer has to surrender carbon allowance $a y_{t} . \alpha$ denotes the carbon emission rate which is defined as the carbon emission amount of consuming one unit of energy. This is similar to the definition by Cao and Li (2014). The consumer with emissions over (or below) the allocated allowance in each stage will purchase (or sell) allowances from the carbon allowance market. Let $x_{t}$ denote the consumer's allowance trading volume at stage $t$. $X_{t}$ is assumed to be positive if the consumer purchases allowances and negative if the consumer sells allowances. In addition the consumer's extra allowance at the end of stage $t-1$ can be transferred to the next stage $t$. At the beginning of stage $t$, the total carbon allowance a consumer owned is defined as the stock of carbon allowances $C_{t}$. Assume that the stock of carbon allowances at the beginning of the emission commitment period is zero $\left(C_{1}=0\right)$ for simplicity. $C_{t+1}$ is composed of three parts, namely $C_{t}, A_{t}$ (allowances allocated at current stage) and $X_{t}$ (allowances purchased or sold). Similarly, at the beginning of stage $t$, the total energy budget is defined as the stock of energy budget $W_{t}$. Without loss of generality, a consumer's stock of energy budget is assumed to be zero at the beginning of the emission commitment period, that is, $W_{1}=0$. At each stage $t$, the energy budget of the consumer is $I_{t}$. For simplicity, energy budget is assumed to be fixed and equal in each stage. I ( $\left.I=\left[I_{1} I_{2} I_{3} \ldots I_{t-1} I_{t}\right]\right)$ denotes the energy budget vector and the elements in the vector are the same, namely, $I_{1}=I_{2}=\ldots=I_{t-1}=I_{t}$. The full list of the variables and parameters of the model is given in Table 1. 
Decision variables

$x_{t} \quad$ Volume of allowance trading at stage t (unit)
$y_{t} \quad$ Energy consumption at stage t (unit)

\section{Parameters}

$\begin{array}{cc}P_{x} & \text { Allowance price vector (\$/unit) } \\ P_{y} & \text { Energy price vector(\$/unit) } \\ A & \text { Allowance allocation vector }(\$) \\ I & \text { Energy budget vector }(\$) \\ \alpha & \text { Carbon emission rate } \\ C_{t} & \text { Stock of carbon allowances at the beginning of stage } t(u n i t) \\ W_{t} & \end{array}$

\subsection{Feasible decision set}

In each stage, the consumer faces the carbon constraints and energy budget constraints. The constraints can be formulated as follows:

$$
\begin{aligned}
& \left(P_{x}\right)_{t} x_{\mathrm{t}}+\left(P_{y}\right)_{t} y_{\mathrm{t}} \leq W_{\mathrm{t}}+I_{t} \\
& a y_{\mathrm{t}} \leq C_{t}+A_{t}+x_{t} \\
& -x_{\mathrm{t}} \leq C_{t}+A_{t}
\end{aligned}
$$

Constraint (1) is the expenditure constraint, which signifies that the expenditure on energy consumption and allowances at stage $t\left(\left(P_{x}\right)_{t} x_{t}+\left(P_{y}\right)_{t} y_{\mathrm{t}}\right)$ should be no more than the total energy budget in this stage $t\left(W_{\mathrm{t}}+I_{t}\right)$. Constraint (2) signifies that the total allowances $\left(C_{t}+A_{t}+x_{t}\right)$ should cover the allowances for surrender in energy 
consumption ( $\left.a y_{\mathrm{t}}\right)$. Constraint (3) guarantees that the consumer could sell no more than $C_{t}+A_{t}$. When $t=T$, equations (1) and (2) represent tight constraints. According to equations (1), (2) and (3), the domain AOBC as the feasible set at stage $t$ is plotted in Figure 1.

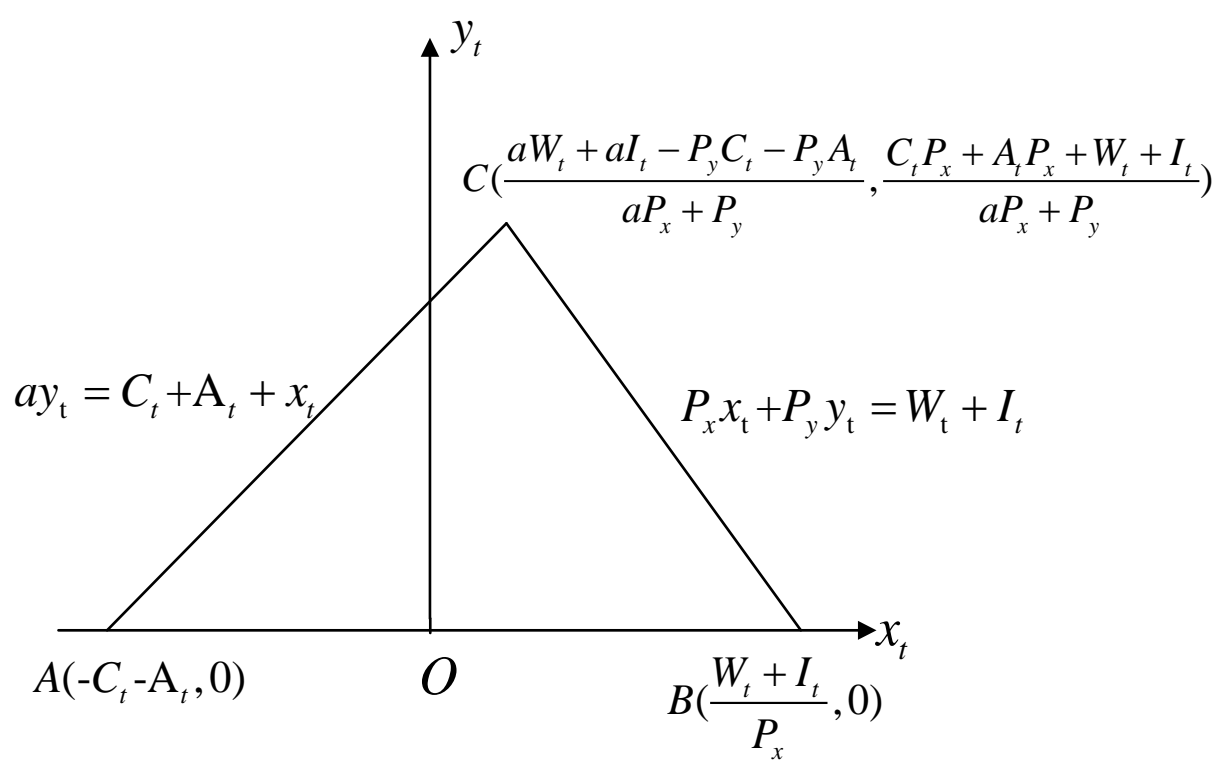

Figure 1 Feasible decision set of a consumer at stage $t$

As shown in Figure 1, $x_{t}<0$ signifies that the consumer could sell carbon allowances to the market and the maximum quantity sold is $C_{t}+A_{t}$ units. On the other hand, $x_{t}>0$ means that the consumer is a buyer with the maximum purchase amount of $\frac{W_{t}+I_{t}}{P_{x}}$ units within the energy budget constraints. Meanwhile in each stage the consumer could consume $\frac{C_{t} P_{x}+A_{t} P_{x}+W_{t}+I_{t}}{a P_{x}+P_{y}}$ units of energy at most.

\subsection{State transfer equation}

In a DP problem, state transfer equation depicts how the system moves from one state to another in the decision process (Denardo, 1982). The sequence and timing of 
events and decisions at stage $t$ are shown in Figure 2. Allowance and energy budget allocation occur at the beginning of each stage $t$. Subsequently the consumer makes decisions about carbon allowance trading and energy consumption. For simplicity, it is assumed that a consumer's decision about allowance trading precedes that about energy consumption. At the beginning of stage $t+1$, the stock of carbon allowances $\left(C_{t+1}\right)$ would equal $C_{t}$ plus allowance allocation $\left(A_{t}\right)$ and allowance trading volume $\left(X_{t}\right)$ and then minus the allowances surrendered for energy consumption $\left(a y_{t}\right)$. Similarly the stock of energy budgets at the end of stage $t\left(W_{t+1}\right)$ would be obtained by adding the energy budget $\left(I_{t}\right)$, and deducting the expenditure on allowance trading $\left(\left(P_{y}\right)_{t} y_{t}\right)$ and energy consumption $\left(\left(P_{x}\right)_{t} x_{t}\right)$ from the stock of energy budgets at the beginning of stage $t\left(W_{t}\right)$. Then the state transfer equations are obtained as follows:

$$
\begin{aligned}
& C_{t+1}=C_{t}+x_{\mathrm{t}}-a y_{\mathrm{t}}+A_{t} \\
& W_{\mathrm{t}+1}=W_{\mathrm{t}}-\left(P_{\mathrm{y}}\right)_{t} y_{t}-\left(P_{x}\right)_{t} x_{t}+I_{t}
\end{aligned}
$$

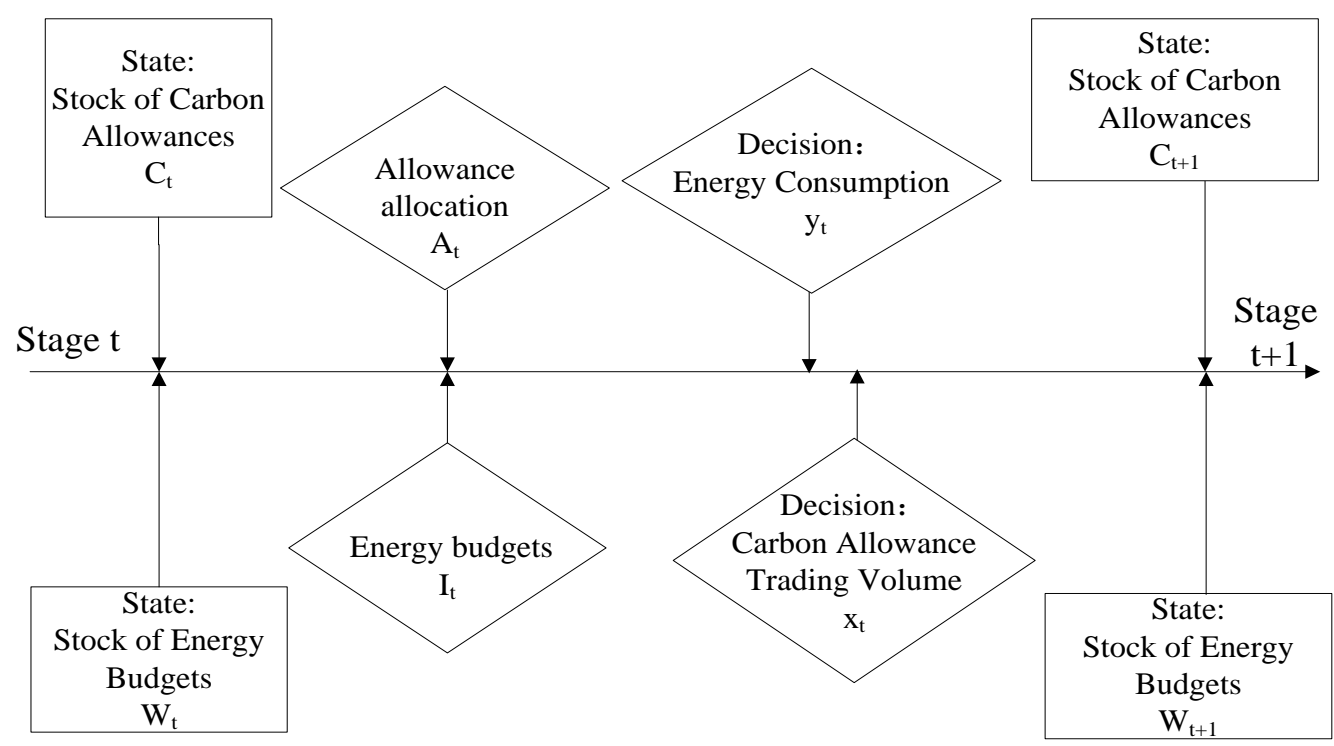

Figure 2 Event line at stage $t$ 


\subsection{Stage Index Function and Optimal Value Function}

In the DP problem, the stage index function is defined as the consumer's utility function in each stage $t$, which is represented by energy consumption $\left(y_{t}\right)$ (Nesbakken, 1999). The optimal value function is defined as the maximization of the consumer's total utility in the emission commitment period. It is assumed that the total utility function in the emission commitment period is the multiplication of utility in each stage, which seems like a logarithmic utility function proposed by Hedenus and Azar (2005). The optimal value function is as follows:

$$
\left\{\begin{array}{l}
\Pi_{t, n}=\max f_{t}\left(S_{t}, y_{t}\right) \Pi_{t+1, n} \\
f_{T+1}\left(S_{T+1}\right)=1
\end{array}\right.
$$

where $\Pi_{t, n}$ denotes the optimal value function defined from stage $t$ to $n ; f_{t}\left(S_{t}, y_{t}\right)$ denotes the stage index function in stage $t$, let $S_{t}$ denote the vector $\left(W_{t}, C_{t}\right) ; f_{T+1}\left(S_{T+1}\right)$ denotes the stage index function with the state variable vector $S_{T+1}$ at the end of stage T. $f_{T+1}\left(S_{T+1}\right)=1$ is the terminal boundary condition in the DP problem when the optimal value function is in a product form.

\section{Numerical simulations and results}

This section presents simulations, results and discussions of the allowance trading volume and energy consumption in an emission commitment period. The paper simulates numerical examples and uses the full search method (FSM), which is a traditional technique to solve the DP problem (Soleymani and Morgera, 1987). This method tries all possible solutions in feasible set to find the optimized one. The DP approach and constraints are explained in Figure 3. Starting from the given boundary condition $\Pi_{T+1}\left(S_{T+1}\right)=1$, the algorithm resolves the optimal function in inverted sequence from stage $T$ to stage 1 . In each stage, the index function is calculated with each possible states and decisions, which subject to the constraints (1), (2) and (3) and the optimal value is obtained by comparing the results. As the state variables at stage 
1 are fixed, the optimal value of decision variables $x_{t}^{*}$ and $y_{t}^{*}$ are presented orderly from stage 1 to $T$.

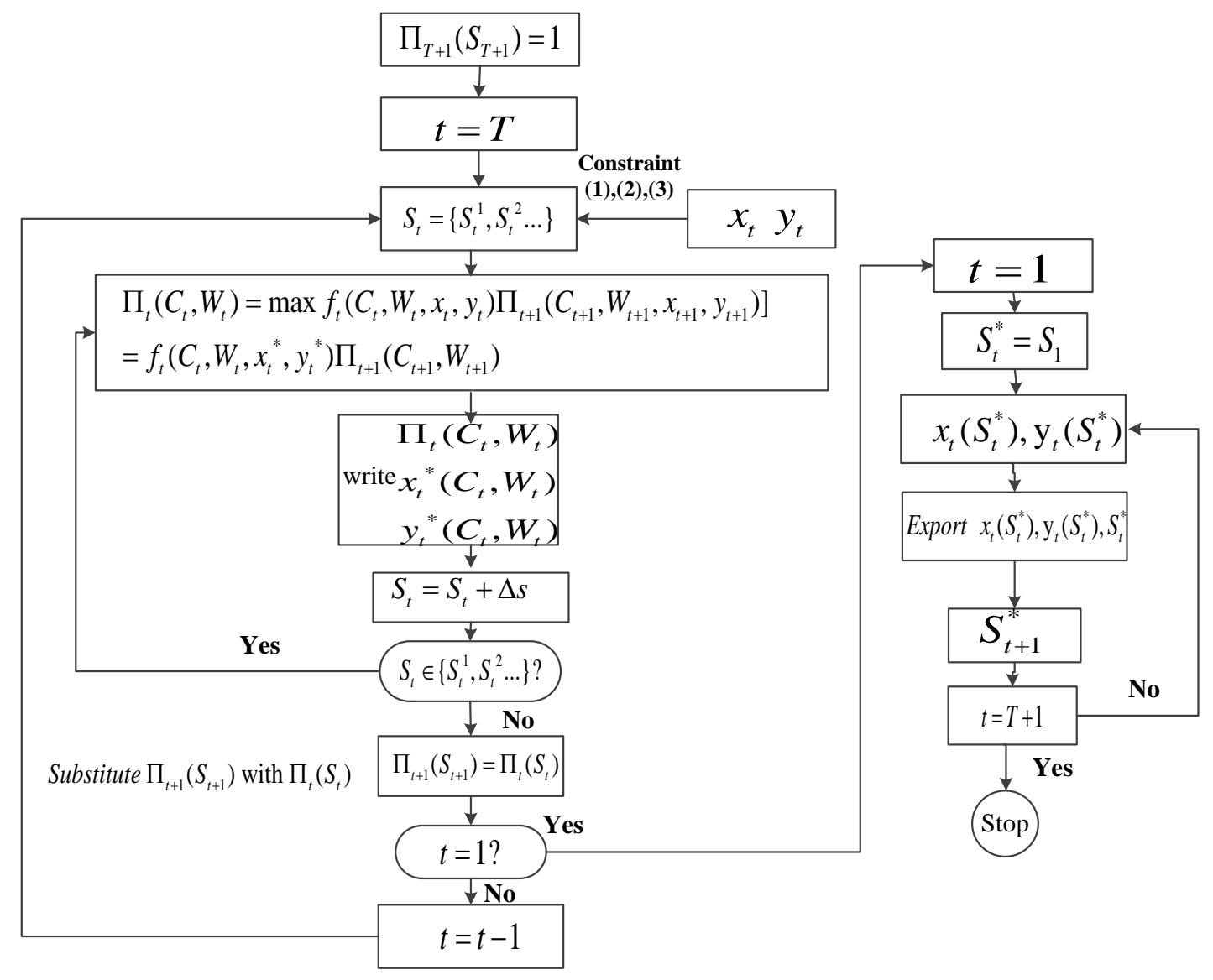

Notes: $\Delta s$ is the step size in the simulation. $S_{t}^{*}$ denotes the optimal value of state variable vector.

Figure 3 Process and algorithm of DP

This paper considers ten different scenarios which cover five different allowance price processes with two carbon emission rates. As the PCT scheme is a novel and untried policy proposal (Simonsen and Warning, 2014), the real data is not available. In this paper simulated data is used to generate a trend instead of accurate numbers. Similar exercises are also reported by Blumberga et al. (2014) and Rieger et al. (2015). The simulated data are presented as follows:

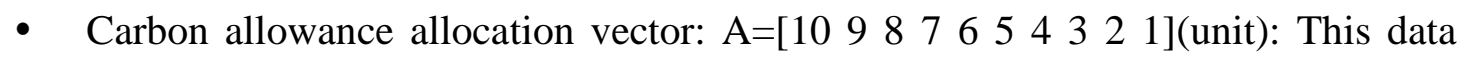


satisfies the assumption that allowance allocation would diminish gradually over time (Fawcett, 2010) and the absolute number would not affect the general trend of the results.

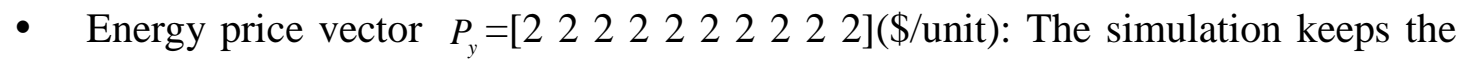
energy price constant in order to investigate exclusively the influence of allowance price on energy consumption and allowance trading (Fan et al., 2015b).

- $\quad$ Stock of carbon allowances in $\mathrm{t}=1: C_{1}=0$ (See Section 3)

- $\quad$ Stock of energy budgets in $\mathrm{t}=1: W_{1}=0 \quad$ (See Section 3)

This paper sets the total model horizon $\mathrm{T}$ to be 10 stages. The allowance prices and their volatilities are shown in Table 2. Scenarios a, b and c (f, g and h) stand for the stable allowance prices in low, medium and high level, respectively. Scenarios d and e ( $\mathrm{i}$ and $\mathrm{j}$ ) stand for the low and high price volatilities. The emission rates of 1 and 2 are chosen to investigate a consumer's response to changes in emission rate and its absolute value would not affect the general trend (Blumberga et al., 2014). The ten simulations are run using MATLAB 2010a.

\subsection{Base run}

To provide a comparison basis of the ten scenarios, this paper sets Scenario b as the base run. In this scenario, the consumer would face a stable allowance price process with a fixed carbon allowance price 1 \$ /unit. The rate of price change $(R O C)$ is introduced to measure carbon price volatility. According to Olivera (2014), the average rate of price change (AROC) is defined as follows:

$$
A R O C=\frac{1}{T-1} \sum_{t=1}^{t=T-1} \frac{P_{t+1}-P_{t}}{P_{t}}
$$

According to (6), AROC equals zero in the base run. 
Table 2 Data in different simulated scenarios

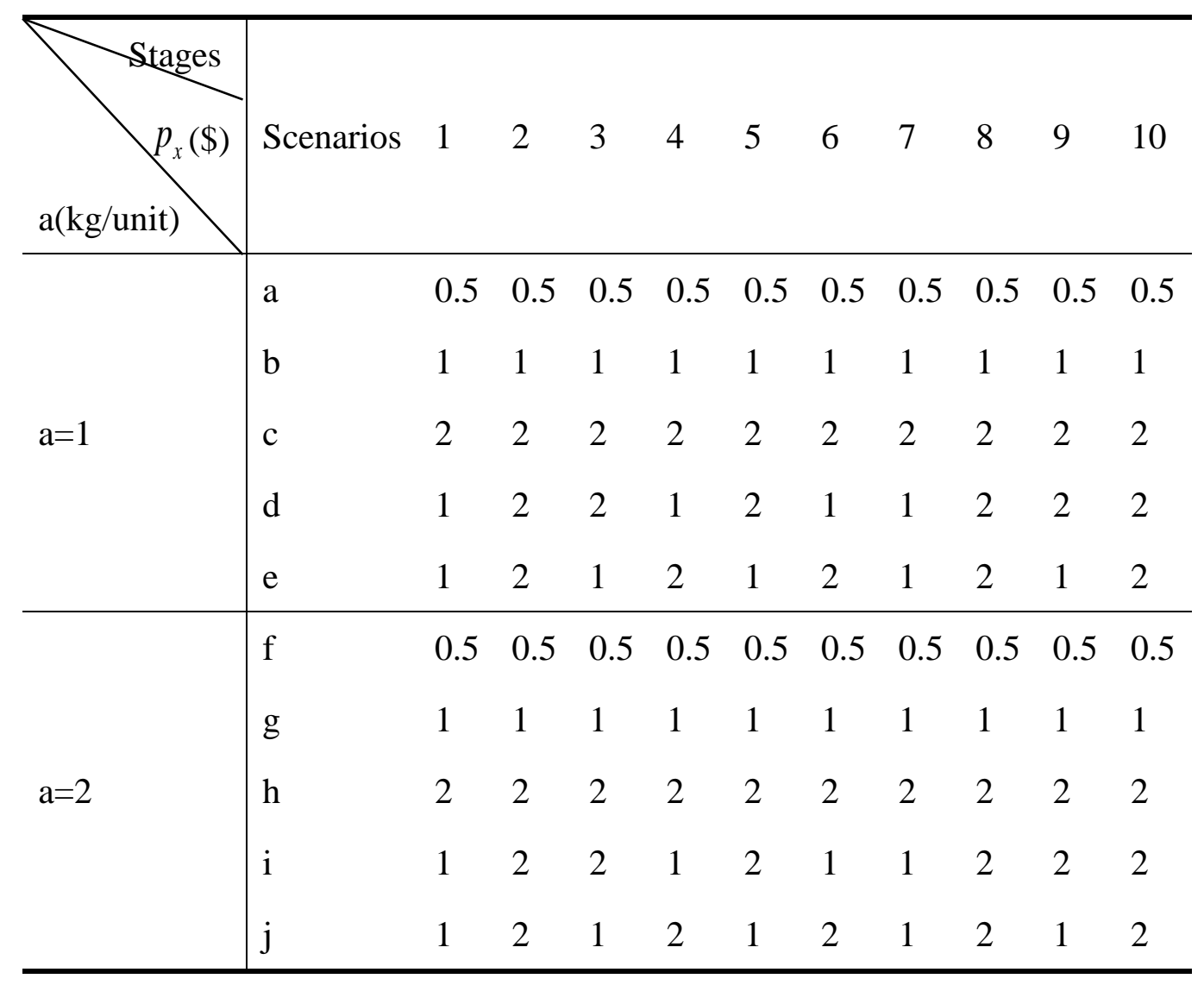

\subsection{Results of three stable allowance price scenarios}

The analysis focuses on investigating the consumer's behavior under different allowance prices ranging from low to high. Two types of carbon emission rates are also considered. Figure 4 presents an intuitive understanding of the allowance trading volume and energy consumption under different allowance prices and carbon emission rates.

\subsection{Carbon allowance trading volume under stable price scenarios}

In the PCT scheme, carbon allowance price would provide the economic incentives for a transition to low-carbon lifestyles (Nelson et al., 2012). The carbon allowance trading volume curve in Figure 4 shows the consumer will tend to buy more or sell less carbon allowances when the carbon emission rate is high $(a=2)$. This means that the consumer has to spend more on energy consumption in this situation. 


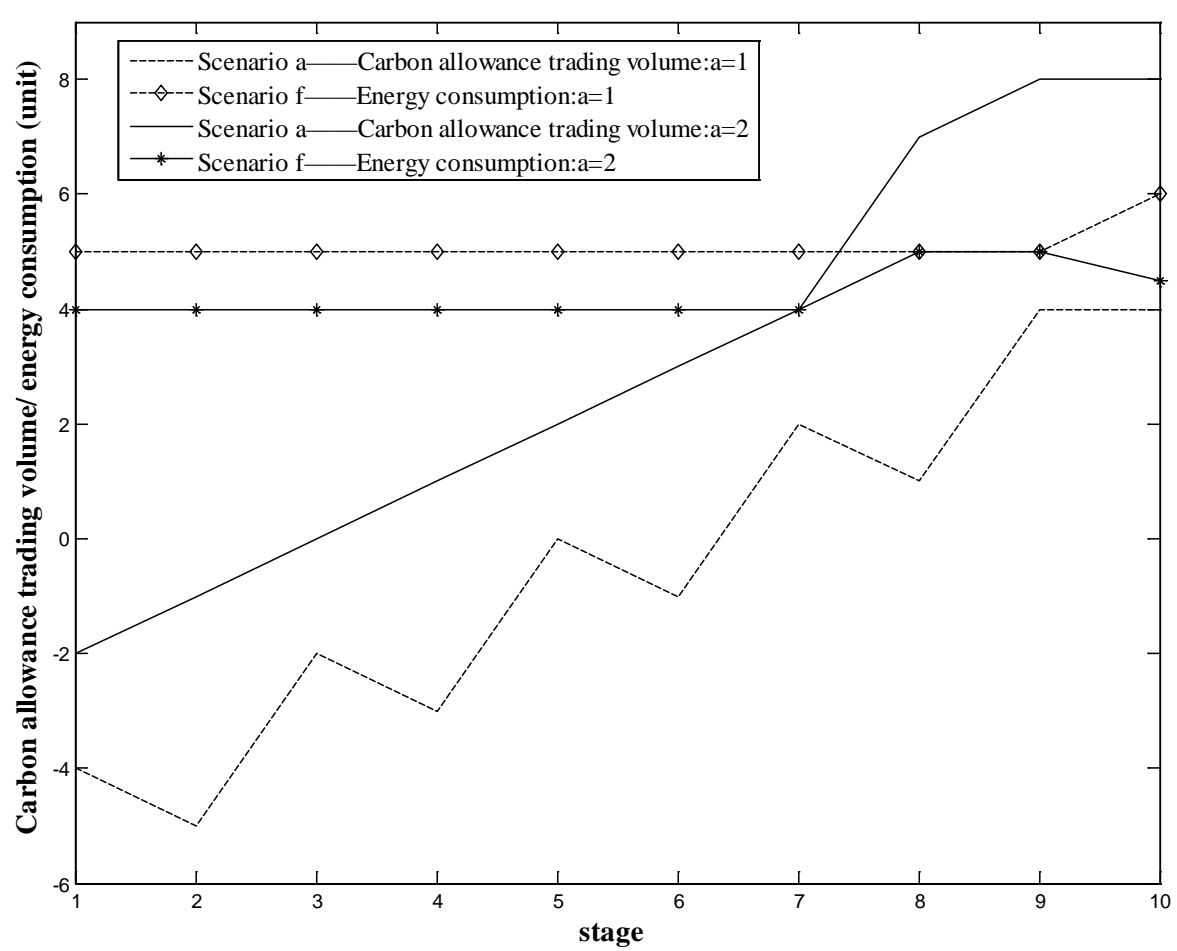

(a) Scenarios a and $\mathrm{f}$

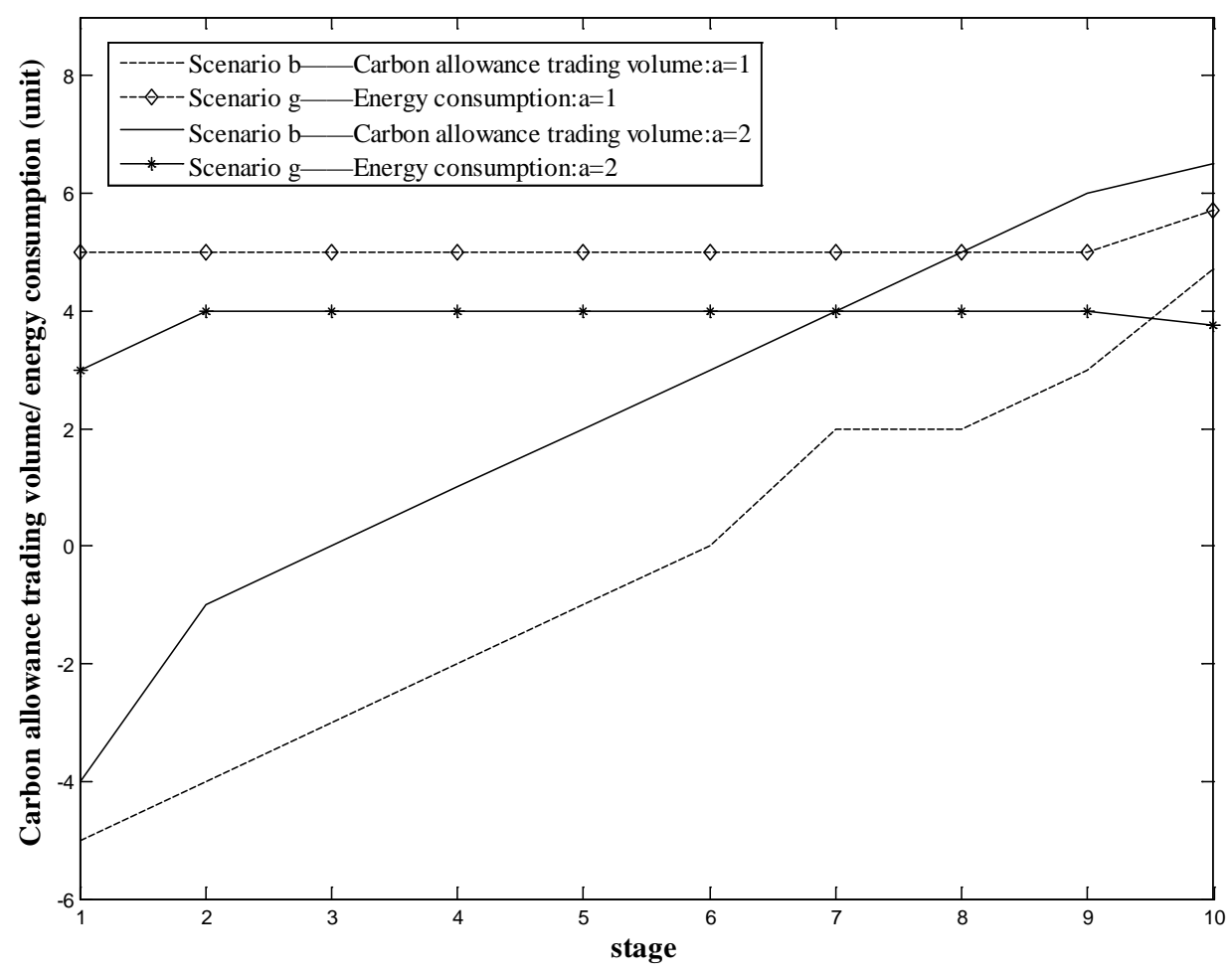

(b) Scenarios b and g 


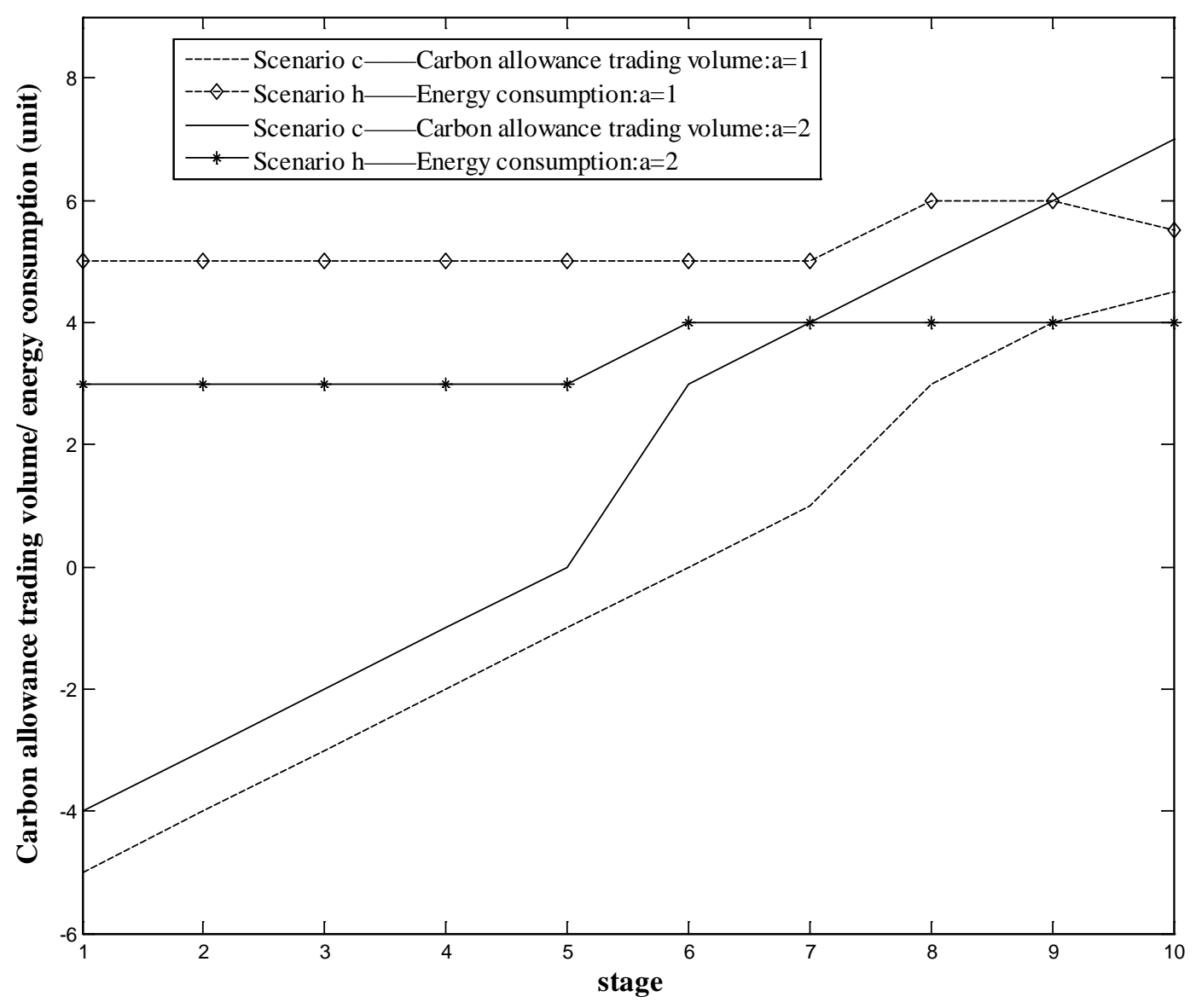

(c) Scenarios c and h

Figure 4 Carbon allowance trading volume and energy consumption under stable price scenarios

Further analysis can illustrate the relationship between the net carbon allowance trading volume and allowance price during the entire emission commitment period. Figure 5 presents an upward-sloping curve for the low emission rate $(a=1)$ and a downward-sloping curve for the high one $(a=2)$. When the carbon emission rate is low, the consumer is a below-allocation emitter who has surplus allowance for sale in the allowance market and hence a net seller (Starkey and Anderson, 2005). As shown in Figure 5 the consumer would sell less allowance as allowance price rises. This finding is consistent with the conclusion drawn by Fan et al. (2015b) through their price effect analysis. When the carbon emission rate is high, the consumer would need more than the allowance allocation to cover energy consumption. In this situation, the consumer 
is a net buyer with a downward-sloping demand curve. In general it is self-evident that a price increase leads to a fall in demand.

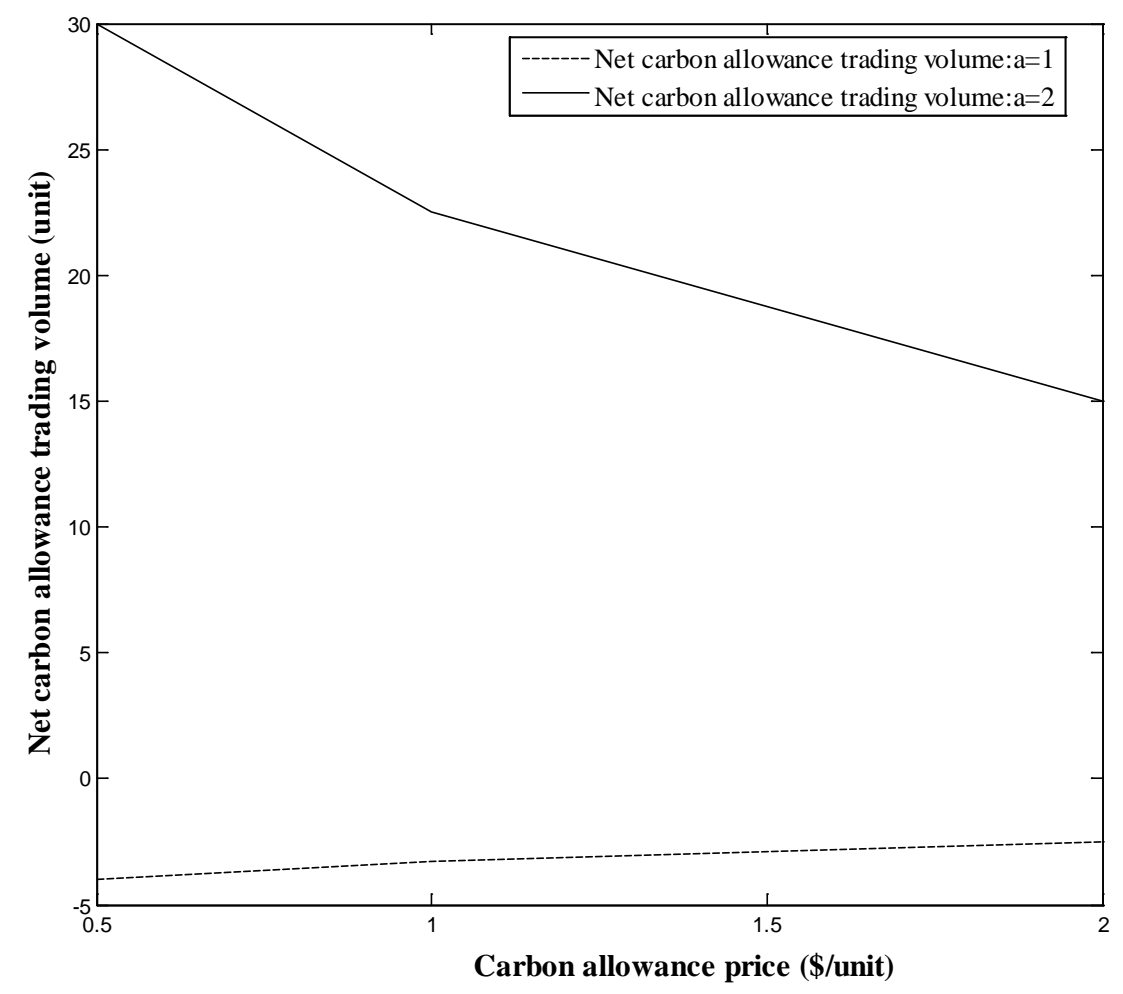

Figure 5 Net carbon allowance trading volume and allowance price

\subsection{Energy consumption under stable price scenarios}

Figure 4 indicates that energy consumption in each stage ranges from 3 to 6 units. Its value is relatively stable regardless of carbon allowance prices. This confirms the argument that a PCT scheme would stabilize energy consumption through allowance banking and borrowing across all periods (Carmona et al., 2010). As indicated by Sorrell (2010), the PCT scheme puts a price on carbon and hence promotes energy use efficiency and emission reductions. If consumers generate more carbon emissions than their allowance allocation, they must borrow allowances from other periods. On the contrary if they emit less than their allowance allocation, they could bank allowances to other periods. Then consumers would balance carbon emissions in the emission commitment period. Furthermore, as shown in Figure 4, consumers would benefit more by reducing their energy consumption under a PCT scheme. Hence the 
introduction of PCT would make consumers aware of their emissions when they are confronted with high carbon emissions (Starkey and Anderson, 2005). As a result, consumers would keep down their energy bills to reduce costs as well as environmental impacts. As Environment and Audit Committee (2008) concluded, the PCT scheme would tend to help individuals to link their own emissions with abatement costs.

Further analysis of the impact of allowance price on energy consumption during the emission commitment period can be conducted. Figure 6 shows that, when the emission rate is low, total energy consumption increases as the allowance price rises. When the carbon emission rate is low, the consumer is a net seller as discussed above. The consumer could convert the surplus allowances into money besides covering energy consumption (Sorrell, 2010). Thus the consumer would obtain more money as allowance price increases, and is hence able to spend more on energy consumption. Conversely when the carbon emission rate is high, the consumer's emission exceeds allocated allowance and thus the consumer has to pay additional money to buy carbon allowances. The higher the allowance price is, the more the consumer has to spend, thus consuming less energy. 


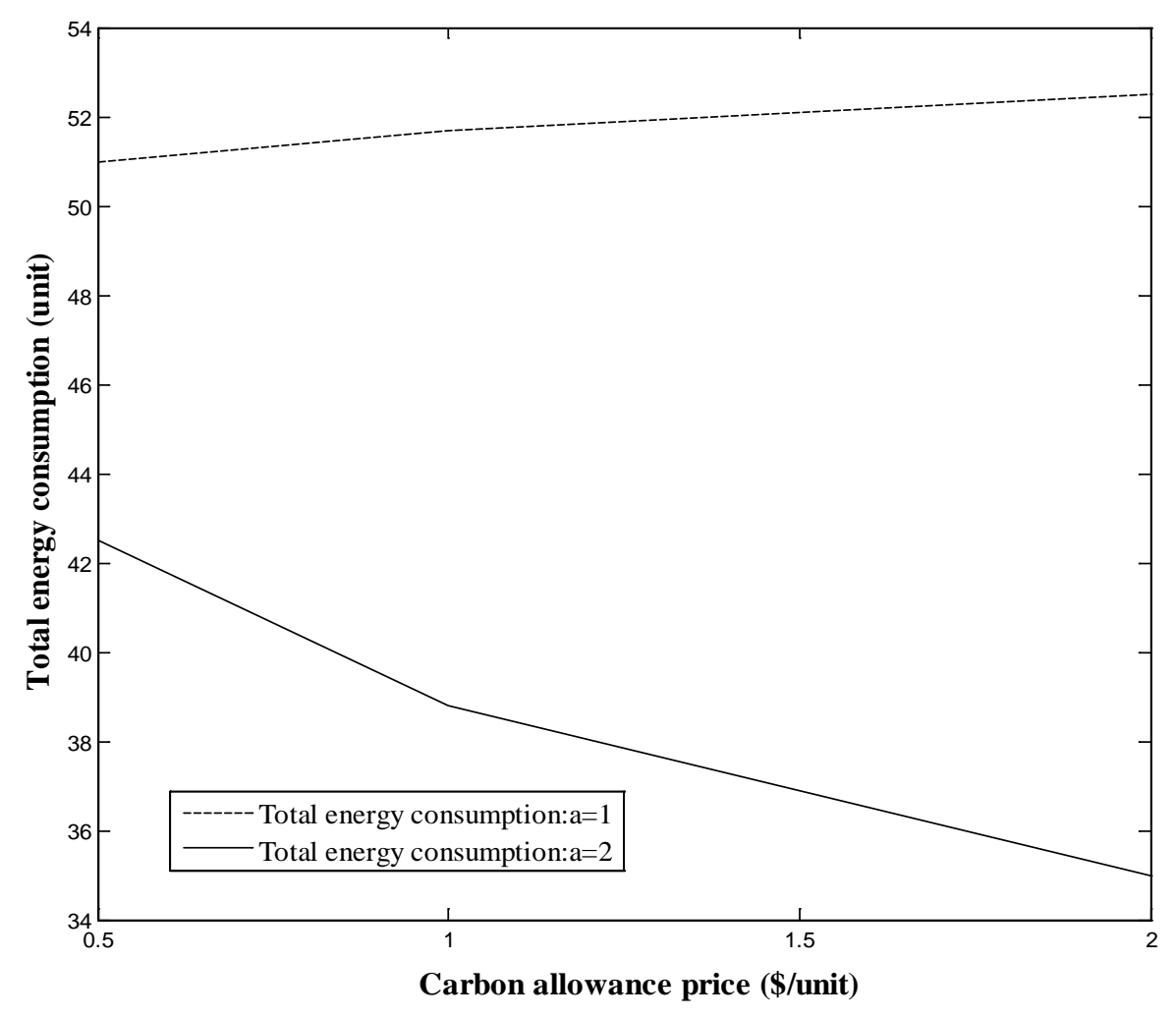

Figure 6 Total energy consumption and carbon allowance price

\subsection{Results of two volatile allowance price scenarios}

This section examines the carbon allowance trading volume and energy consumption under two different allowance price volatilities. Two kinds of carbon emission rates are also considered. Figure 7 illustrates that the consumer tends to trade more actively in the allowance market under the volatile price scenarios. It is observed that a large allowance trading volume is accompanied by a rise in allowance price and a small volume is associated with a decrease in price. This pattern is consistent with the empirical findings in the financial market by Karpoff (1987). Also Başci et al. (1996) indicated that the trading volume is positively related to the prices in some emerging markets, since these markets are considered to be of a more speculative nature. Karpoff (1987) argued that the trading volume positively correlates with the magnitude of price changes. Obviously the PCT is of speculative nature, providing the basis for the derivations of carbon futures, carbon options, and so on. 


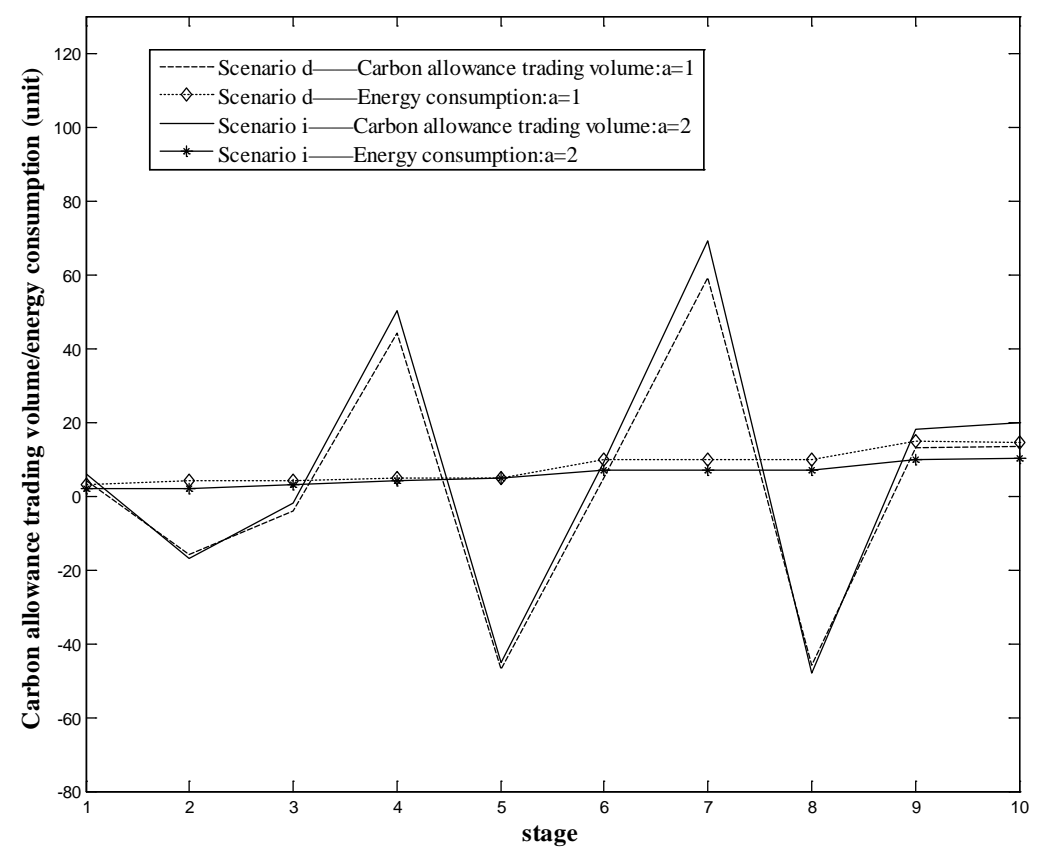

(a) Scenarios d and i

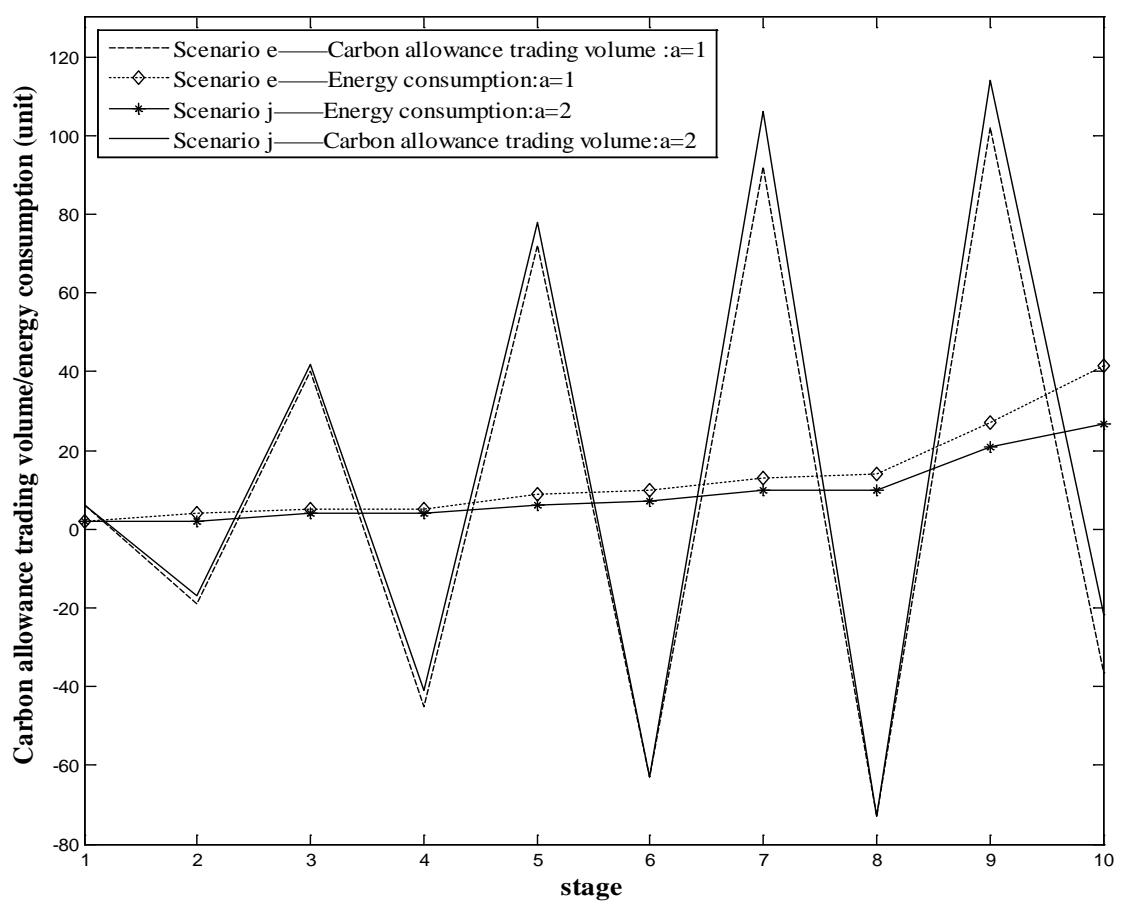

(b) Scenarios e and j

Figure 7 Carbon allowance trading volume and energy consumption under two volatile price scenarios 
Figure 8 can show a more detailed relationship between allowance trading volume and allowance price volatility during the emission commitment period. It is shown that the net carbon allowance trading volume positively correlates with the average rate of price change during the emission commitment period. It signifies that the consumer would trade more actively when price is more volatile. Furthermore higher carbon emission rates may make the consumer more likely to trade carbon allowances to benefit more from the increase of the average rate of price change (Figure 8). As mentioned above, the consumer would need more carbon allowances to surrender for energy with a high emissions rate.

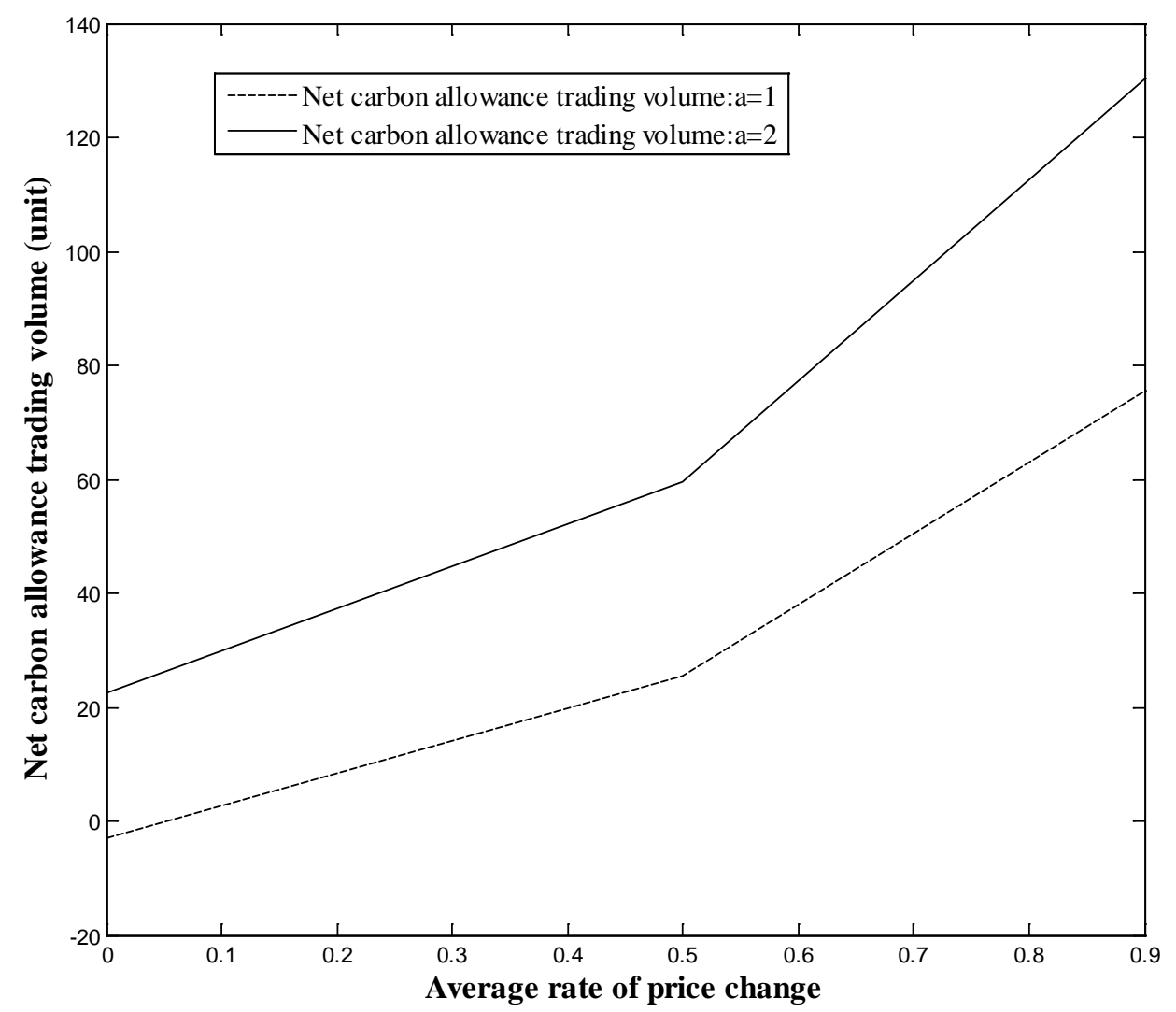

Figure 8 Net carbon allowance trading volume and price volatility

As shown in Figure 7, the consumer's energy consumption would be quite stable even if allowance price is volatile. Additionally, similar to the stable allowance price scenarios, the consumer would reduce energy consumption when the carbon emission 
rate is high. The relationship between total energy consumption and price volatility during the emission commitment period is further investigated in Figure 9. The total energy consumption will increase when the allowance price becomes more volatile (Figure 9). The consumer would tend to trade more actively in a more volatile price scenario to gain more benefits. Furthermore, as discussed above, the consumer would cut the energy consumption when the carbon emission rate becomes high (Figure 9).

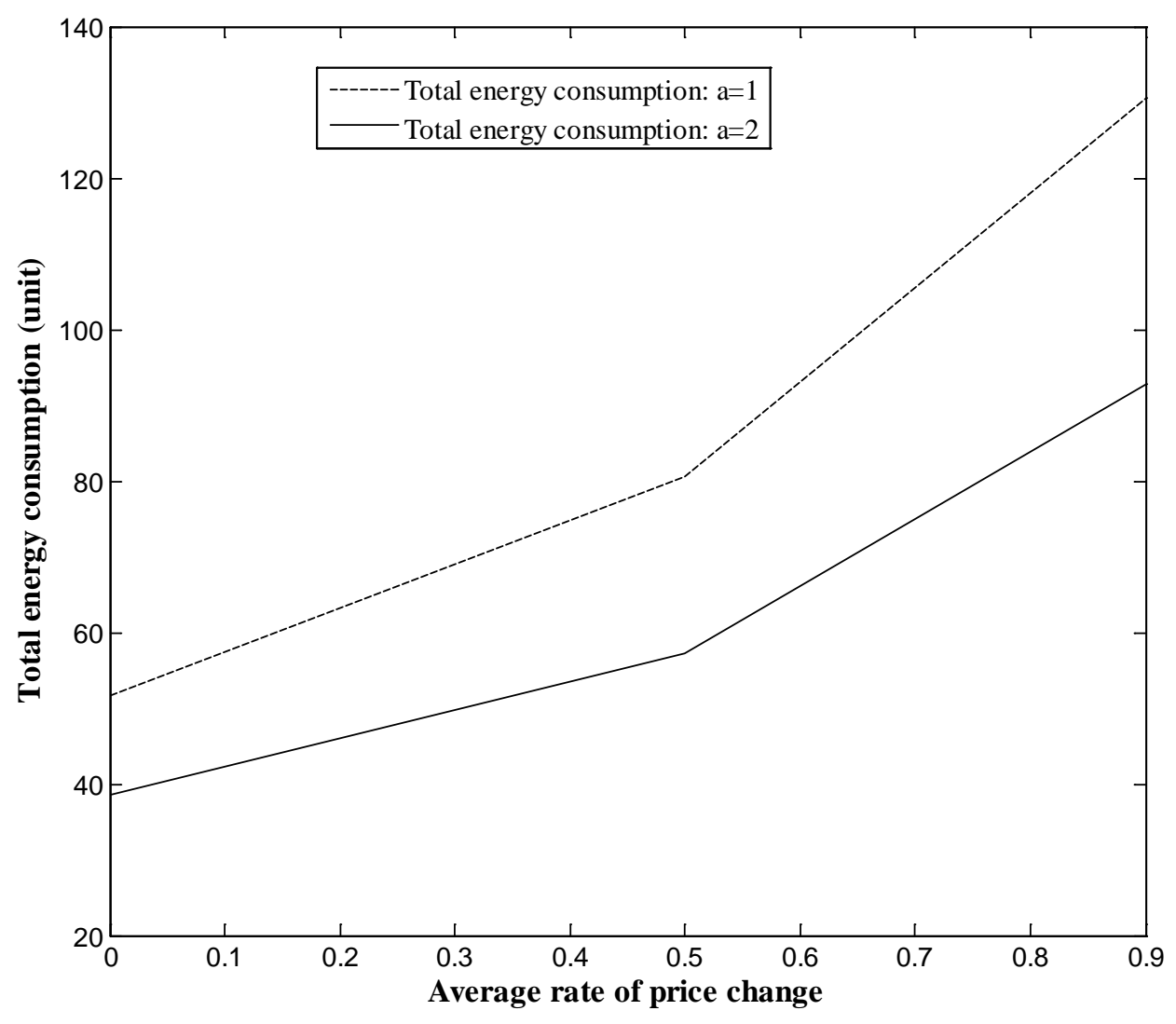

Figure 9 Total energy consumption and price volatility

\section{Conclusions, policy implications and future studies}

The PCT scheme is a novel policy instrument which aims to provide market signals and incentives to facilitate low carbon lifestyles in the household sector (Parag et al., 2011). This paper contributes to the PCT literature by investigating the dynamic allowance trading and energy consumption and taking into consideration of allowance banking and borrowing. A DP model is developed to simulate several scenarios with 
different allowance prices, price volatility and carbon emission rates.

It is found that the allowance price could play an important role in stimulating behavioral changes in a PCT scheme. This conclusion is derived from a dynamic perspective. It is also consistent with the findings by others such as Fan et al. (2015b) and Raux et al. (2015) who conducted static analyses. Furthermore, with the introduction of PCT, consumers would reduce energy consumption when the carbon emission rate is high. It is also found that consumers trade actively in the allowance market when great allowance price volatility is present. This concurs with economic theory and is similar to the phenomena observed in the existing market (Karpoff, 1987). Price volatility in the carbon market would affect the effectiveness of the PCT scheme in carbon abatement, which is similar to the emissions trading scheme in upstream sectors (Xu et al., 2014). The findings in this paper would be valuable for the introduction and implementation of the PCT scheme. Regulators should be cautious about the allowance price and its volatility. It is advisable to establish the carbon price "floors and ceilings" (Jacoby and Ellerman, 2004) to confine the spot price to a desired range in the PCT scheme and associated carbon derivative market.

However this research has its limitations. Future research should develop more realistic models which can deal with consumers' heterogeneity (Allenby et al., 1998) and transaction cost (Fan et al., 2015a). Additionally, due to the limitation of data availability, conclusions in this paper are based on simulated data. The actual transaction data under a PCT scheme would yield more interesting and applicable results.

\section{Acknowledgements}

The authors acknowledge the National Natural Science Foundation of China (71301157, 71171183) for their generous financial support. They also acknowledge the editor of the journal and four anonymous referees for their careful reading and constructive comments. 


\section{References}

Allenby, G.M., Arora, N., Ginter, J.L., 1998. On the heterogeneity of demand. Journal of Marketing Research 35 (3), 384-389.

Başci, E., Özyildirim, S., Aydoan, K., 1996. A note on price-volume dynamics in an emerging stock market. Journal of Banking \& Finance 20(2), 389-400.

Bessembinder, H., Seguin, P.J., 1992. Futures-trading activity and stock price volatility. The Journal of Finance 47(5), 2015-2034.

Bistline, J.E., Weyant, J.P., 2013. Electric sector investments under technological and policy-related uncertainties: a stochastic programming approach. Climatic change 121(2), 143-160.

Blumberga, A., Blumberga, D., Bazbauers, G., Zogla, G., Laicane, I., 2014. Sustainable development modelling for the energy sector. Journal of Cleaner Production 63(15), 134-142.

Brauneis, A., Mestel, R., Palan, S., 2013. Inducing low-carbon investment in the electric power industry through a price floor for emissions trading. Energy Policy 53, 190-204.

Cao, H., Li, H., 2014. Simulation-based approach to modeling the carbon emissions dynamic characteristics of manufacturing system considering disturbances. Journal of Cleaner Production 64, 572-580.

Capstick, S.B., Lewis, A., 2008. Personal Carbon Trading: Perspectives from Psychology and Behavioral Economics. Institute for Public Policy Research, London, UK.

Capstick, S.B., Lewis, A., 2010. Effects of personal carbon allowances on decision-making: Evidence from an experimental simulation. Climate Policy 10(4), 369-384.

Carmona, R., Fehr, M., Hinz, J., Porchet, A., 2010. Market design for emission trading schemes. Siam Review 52(3), 403-452.

Cohen, M.J., 2011. Is the UK preparing for “war”? Military metaphors, personal carbon allowances, and consumption rationing in historical perspective. Climatic Change 104(2), 199-222. 
Denardo, E.V., 1982. Dynamic Programming: Models and Applications. Prentice-Hall, Englewood Cliffs, NJ.

Environmental Audit Committee, 2008. Personal Carbon Trading. House of Commons. 5th Report, London, UK.

Fan, J., Guo, X., Marinova, D., Wu, Y., Zhao, D., 2012. Embedded carbon footprint of Chinese urban households: Structure and changes. Journal of Cleaner Production 33, 50-59.

Fan, J., Wang, S., Wu, Y., Li, J., Zhao, D., 2015a. Energy-use choice and allowance trading under the personal carbon trading scheme. Natural Resource Modeling 28(1), 1-17.

Fan, J., Wang, S., Wu, Y., Li, J., Zhao, D., 2015b. Buffer effect and price effect of a personal carbon trading scheme. Energy 82, 601-610.

Fawcett, T., 2010. Personal carbon trading: A policy ahead of its time? Energy Policy 38(11), 6868-6876.

Fleming, D., 1997. Tradable quotas: Using information technology to cap national carbon emissions. European Environment 7(5), 139-148.

Fleming, D., 2005. Energy and the Eommon Purpose: Descending the Energy Staircase with Tradable Energy Quotas (TEQs), the Lean Economy Connection, London, UK.

Godard, O., 2001. Domestic Transferable Permits for Environmental Management: Design and Implementation, Paris, OECD Publ., June.

Gosavi, A., 2015. Simulation-based Optimization: An Overview. In Simulation-Based Optimization (pp. 29-35). Springer US.

Harwatt, H., Tight, M., Bristow A.L., Gühnemann, A., 2011. Personal carbon trading and fuel price increases in the transport sector: An exploratory study of public response in the UK. European Transport 47 (16), 47-70.

Hedenus, F., Azar, C., 2005. Estimates of trends in global income and resource inequalities. Ecological Economics 55(3), 351-364.

Herring, H., 2006. Energy efficiency: A critical view. Energy 31(1), 10-20.

Hillman, M., 1998. Carbon budget watchers: the implications for individual lifestyles. 
Town and Country Planning-London-Town and Country Planning Association 67, 305-305.

Howell, R.A., 2012. Living with a carbon allowance: The experiences of carbon rationing action groups and implications for policy. Energy Policy 41, 250-258.

Ilic, D.D., Dotzauer, E., Trygg, L., Broman, G., 2014. Introduction of large-scale biofuel production in a district heating system-an opportunity for reduction of global greenhouse gas emissions. Journal of Cleaner Production 64, 552-561.

Jacoby, H.D., Ellerman, A.D., 2004. The safety valve and climate policy. Energy Policy 32(4), 481-491.

Karpoff, J.M., 1987. The relation between price changes and trading volume: A survey. Journal of Financial and Quantitative Analysis 22(1), 109-126.

Lenzen, M., Murray, S.A., 2001. A modified ecological footprint method and its application to Australia. Ecological Economics 37(2), 229-255.

Li, J., Fan, J., Zhao, D., Wang, S., 2014. Allowance price and distributional effects under a personal carbon trading scheme. Journal of Cleaner Production.

Available on line at http://www.sciencedirect.com/science/article/pii/S0959652 614009044.

McNamara, D., Caulfield, B., 2013. Examining the impact of carbon price changes under a personalised carbon trading scheme for transport. Transport Policy 30, 238-253.

Murata, A., Kondou, Y., Hailin, M., Weisheng, Z., 2008. Electricity demand in the Chinese urban household-sector. Applied Energy 85(12), 1113-1125.

National Bureau of Statistics of China-NBSC, 2014. 2013 China Energy Statistical Yearbook. Energy Bureau of Statistics Press and China Statistics Press, Beijing (in Chinese).

Nelson, T., Kelley, S., Orton, F., 2012. A literature review of economic studies on carbon pricing and Australian wholesale electricity markets. Energy Policy 49, 217-224.

Nesbakken, R., 1999. Price sensitivity of residential energy consumption in Norway. Energy Economics 21(6), 493-515. 
Nissinen, A., Heiskanen, E., Perrels, A., Berghäll, E., Liesimaa, V., Mattinen, M.K., 2014. Combinations of policy instruments to decrease the climate impacts of housing, passenger transport and food in Finland. Journal of Cleaner Production. Available on line at http://www.sciencedirect.com/science/article/pii/S0959652 614009184.

Olivera, J.H., 2014. Money, prices and fiscal lags: A note on the dynamics of inflation. PSL Quarterly Review 20(82), 258-267.

Parag, Y., Capstick, S., Poortinga, W., 2011. Policy attribute framing: A comparison between three policy instruments for personal emissions reduction. Journal of Policy Analysis and Management 30(4), 889-905.

Parag, Y., Strickland, D., 2009, Personal Carbon Budgeting: What People Need to Know, Learn and Have in Order to Manage and Live Within a Carbon Budget, and the Policies that Could Support Them, UKERC Research Report - Demand Reduction Theme.

Parsons, J.E., Ellerman, A.D., Feilhauer, S., 2009. Designing a US market for $\mathrm{CO}_{2}$. Journal of Applied Corporate Finance 21(1), 79-86.

Pringles, R., Olsina, F., Garcés, F., 2015. Real option valuation of power transmission investments by stochastic simulation. Energy Economics 47, 215-226.

Raux, C., 2010. The potential for $\mathrm{CO}_{2}$ emissions trading in transport: The case of personal vehicles and freight. Energy Efficiency 3(2), 133-148.

Raux, C., Croissant, Y., Pons, D., 2015. Would personal carbon trading reduce travel emissions more effectively than a carbon tax? Transportation Research Part D: Transport and Environment 35, 72-83.

Rieger, J., Weiss, C., Rummer, B., 2015. Modelling and control of pollutant formation in blast stoves. Journal of Cleaner Production 88, 254-261.

Roberts, S., Thumim, J., 2006. A Rough Guide to Individual Carbon Trading: The Ideas, the Issues and the Next Steps. Report to DEFRA from the Centre for Sustainable Energy.

Rood, G.A., Ros, J.P.M., Drissen, E., Vringer, K., 2003. A structure of models for future projections of environmental pressure due to consumption. Journal of 
Cleaner Production 11(5), 491-498.

Roy, J., Pal, S., 2009. Lifestyles and climate change: Link awaiting activation. Current Opinion in Environmental Sustainability 1, 192-200.

Seyfang, G., 2007. Personal Carbon Trading: Lessons from Complementary Currencies. University of East Anglia, Norwich.

Simonsen, F., Warning, L., 2014. Personal carbon trading: A stepwise approach to implementation. Maastricht University Journal of Sustainability Studies 2, 49-64.

Soleymani, M., Morgera, S.D., 1987. An efficient nearest neighbor search method. Communications, IEEE Transactions on 35(6), 677-679.

Sorrell, S., 2010. An upstream alternative to personal carbon trading. Climate Policy 10(4), 481-486.

Starkey, R., Anderson, K., 2005. Domestic Tradable Quotas: A Policy Instrument for Reducing Greenhouse Gas Emissions from Energy Use. Tyndall Centre for Climate Change Research, Norwich, UK.

Wadud, Z., Noland, R.B., Graham, D.J., 2008. Equity analysis of personal tradable carbon permits for the road transport sector. Environmental Science \& Policy 11(6), 533-544.

Wallace, A., 2009. Reducing Carbon Emissions by Households: the Effects of Footprinting and Personal Allowances, Doctoral thesis, De Montfort University, Leicester, UK.

Wallace, A.A., Irvine, K.N., Wright, A.J., Fleming, P.D., 2010. Public attitudes to personal carbon allowances: Findings from a mixed-method study. Climate Policy 10(4), 385-409.

Wang, X., Cai, Y., Xu, Y., Zhao, H., Chen, J., 2014. Optimal strategies for carbon reduction at dual levels in China based on a hybrid nonlinear grey-prediction and quota-allocation model. Journal of Cleaner Production 83, 185-193.

Xu, L., Deng, S.J., Thomas, V.M., 2014. Carbon emission permit price volatility reduction through financial options. Energy Economics. Available on line at http://www.sciencedirect.com/science/article/pii/S0140988314001248.

Yuan, J., Xu, Y., 2011. China’s Eleventh Five Year Plan GDP Energy Intensity 
Target--Policy Appraisal. In Power and Energy Engineering Conference (APPEEC), 2011 Asia-Pacific (pp. 1-4). IEEE.

Zanni, A.M., Bristow, A.L., Wardman, M., 2013. The potential behavioral effect of personal carbon trading: results from an experimental survey. Journal of Environmental Economics and Policy 2(2), 222-243.

Zhu, Q., Lujia, F., Mayyas, A., Omar, M.A., Al-Hammadi, Y., Al Saleh, S., 2014. Production energy optimization using low dynamic programming, a decision support tool for sustainable manufacturing. Journal of Cleaner Production.

Available on line at http://www.sciencedirect.com/science/article/pii/S0959652 614002297. 
Editor, UWA Economics Discussion Papers:

Sam Hak Kan Tang

University of Western Australia

35 Sterling Hwy

Crawley WA 6009

Australia

Email: ecoadmin@biz.uwa.edu.au

The Economics Discussion Papers are available at:

1980 - 2002: $\quad$ http://ecompapers.biz.uwa.edu.au/paper/PDF\%20of\%20Discussion\%20Papers/

Since 2001: http://ideas.repec.org/s/uwa/wpaper1.html

Since 2004: http://www.business.uwa.edu.au/school/disciplines/economics

\begin{tabular}{|c|c|c|}
\hline \multicolumn{3}{|c|}{$\begin{array}{c}\text { ECONOMICS DISCUSSION PAPERS } \\
2013\end{array}$} \\
\hline $\begin{array}{l}\text { DP } \\
\text { NUMBER }\end{array}$ & AUTHORS & TITLE \\
\hline 13.01 & $\begin{array}{l}\text { Chen, M., Clements, K.W. and } \\
\text { Gao, G. }\end{array}$ & THREE FACTS ABOUT WORLD METAL PRICES \\
\hline 13.02 & Collins, J. and Richards, O. & $\begin{array}{l}\text { EVOLUTION, FERTILITY AND THE AGEING } \\
\text { POPULATION }\end{array}$ \\
\hline 13.03 & $\begin{array}{l}\text { Clements, K., Genberg, H., Harberger, } \\
\text { A., Lothian, J., } \\
\text { Mundell, R., Sonnenschein, H. and } \\
\text { Tolley, G. }\end{array}$ & LARRY SJAASTAD, 1934-2012 \\
\hline 13.04 & Robitaille, M.C. and Chatterjee, I. & MOTHERS-IN-LAW AND SON PREFERENCE IN INDIA \\
\hline 13.05 & Clements, K.W. and Izan, I.H.Y. & $\begin{array}{l}\text { REPORT ON THE } 25^{\mathrm{TH}} \text { PHD CONFERENCE IN } \\
\text { ECONOMICS AND BUSINESS }\end{array}$ \\
\hline 13.06 & Walker, A. and Tyers, R. & QUANTIFYING AUSTRALIA’S “THREE SPEED” BOOM \\
\hline 13.07 & $\mathrm{Yu}, \mathrm{F}$. and $\mathrm{Wu}, \mathrm{Y}$. & PATENT EXAMINATION AND DISGUISED PROTECTION \\
\hline 13.08 & Yu, F. and Wu, Y. & $\begin{array}{l}\text { PATENT CITATIONS AND KNOWLEDGE SPILLOVERS: } \\
\text { AN ANALYSIS OF CHINESE PATENTS REGISTER IN THE } \\
\text { US }\end{array}$ \\
\hline 13.09 & Chatterjee, I. and Saha, B. & BARGAINING DELEGATION IN MONOPOLY \\
\hline 13.10 & Cheong, T.S. and Wu, Y. & $\begin{array}{l}\text { GLOBALIZATION AND REGIONAL INEQUALITY IN } \\
\text { CHINA }\end{array}$ \\
\hline 13.11 & Cheong, T.S. and Wu, Y. & INEQUALITY AND CRIME RATES IN CHINA \\
\hline 13.12 & Robertson, P.E. and Ye, L. & ON THE EXISTENCE OF A MIDDLE INCOME TRAP \\
\hline 13.13 & Robertson, P.E. & THE GLOBAL IMPACT OF CHINA’S GROWTH \\
\hline 13.14 & $\begin{array}{l}\text { Hanaki, N., Jacquemet, N., } \\
\text { Luchini, S., and Zylbersztejn, A. }\end{array}$ & $\begin{array}{l}\text { BOUNDED RATIONALITY AND STRATEGIC } \\
\text { UNCERTAINTY IN A SIMPLE DOMINANCE SOLVABLE } \\
\text { GAME }\end{array}$ \\
\hline 13.15 & $\begin{array}{l}\text { Okatch, Z., Siddique, A. and } \\
\text { Rammohan, A. }\end{array}$ & $\begin{array}{l}\text { DETERMINANTS OF INCOME INEQUALITY IN } \\
\text { BOTSWANA }\end{array}$ \\
\hline 13.16 & Clements, K.W. and Gao, G. & $\begin{array}{l}\text { A MULTI-MARKET APPROACH TO MEASURING THE } \\
\text { CYCLE }\end{array}$ \\
\hline 13.17 & Chatterjee, I. and Ray, R. & $\begin{array}{l}\text { THE ROLE OF INSTITUTIONS IN THE INCIDENCE OF } \\
\text { CRIME AND CORRUPTION }\end{array}$ \\
\hline 13.18 & Fu, D. and Wu, Y. & $\begin{array}{l}\text { EXPORT SURVIVAL PATTERN AND DETERMINANTS } \\
\text { OF CHINESE MANUFACTURING FIRMS }\end{array}$ \\
\hline
\end{tabular}




\begin{tabular}{|c|c|c|}
\hline 13.19 & Shi, X., Wu, Y. and Zhao, D. & $\begin{array}{l}\text { KNOWLEDGE INTENSIVE BUSINESS SERVICES AND } \\
\text { THEIR IMPACT ON INNOVATION IN CHINA }\end{array}$ \\
\hline 13.20 & $\begin{array}{l}\text { Tyers, R., Zhang, Y. and } \\
\text { Cheong, T.S. }\end{array}$ & $\begin{array}{l}\text { CHINA'S SAVING AND GLOBAL ECONOMIC } \\
\text { PERFORMANCE }\end{array}$ \\
\hline 13.21 & Collins, J., Baer, B. and Weber, E.J. & $\begin{array}{l}\text { POPULATION, TECHNOLOGICAL PROGRESS AND THE } \\
\text { EVOLUTION OF INNOVATIVE POTENTIAL }\end{array}$ \\
\hline 13.22 & Hartley, P.R. & THE FUTURE OF LONG-TERM LNG CONTRACTS \\
\hline 13.23 & Tyers, R. & $\begin{array}{l}\text { A SIMPLE MODEL TO STUDY GLOBAL } \\
\text { MACROECONOMIC INTERDEPENDENCE }\end{array}$ \\
\hline 13.24 & McLure, M. & $\begin{array}{l}\text { REFLECTIONS ON THE QUANTITY THEORY: PIGOU IN } \\
1917 \text { AND PARETO IN 1920-21 }\end{array}$ \\
\hline 13.25 & Chen, A. and Groenewold, N. & $\begin{array}{l}\text { REGIONAL EFFECTS OF AN EMISSIONS-REDUCTION } \\
\text { POLICY IN CHINA: THE IMPORTANCE OF THE } \\
\text { GOVERNMENT FINANCING METHOD }\end{array}$ \\
\hline 13.26 & Siddique, M.A.B. & $\begin{array}{l}\text { TRADE RELATIONS BETWEEN AUSTRALIA AND } \\
\text { THAILAND: } 1990 \text { TO } 2011\end{array}$ \\
\hline 13.27 & Li, B. and Zhang, J. & $\begin{array}{l}\text { GOVERNMENT DEBT IN AN INTERGENERATIONAL } \\
\text { MODEL OF ECONOMIC GROWTH, ENDOGENOUS } \\
\text { FERTILITY, AND ELASTIC LABOR WITH AN } \\
\text { APPLICATION TO JAPAN }\end{array}$ \\
\hline 13.28 & Robitaille, M. and Chatterjee, I. & $\begin{array}{l}\text { SEX-SELECTIVE ABORTIONS AND INFANT } \\
\text { MORTALITY IN INDIA: THE ROLE OF PARENTS’ } \\
\text { STATED SON PREFERENCE }\end{array}$ \\
\hline 13.29 & Ezzati, P. & $\begin{array}{l}\text { ANALYSIS OF VOLATILITY SPILLOVER EFFECTS: } \\
\text { TWO-STAGE PROCEDURE BASED ON A MODIFIED } \\
\text { GARCH-M }\end{array}$ \\
\hline 13.30 & Robertson, P. E. & $\begin{array}{l}\text { DOES A FREE MARKET ECONOMY MAKE AUSTRALIA } \\
\text { MORE OR LESS SECURE IN A GLOBALISED WORLD? }\end{array}$ \\
\hline 13.31 & $\begin{array}{l}\text { Das, S., Ghate, C. and } \\
\text { Robertson, P. E. }\end{array}$ & $\begin{array}{l}\text { REMOTENESS AND UNBALANCED GROWTH: } \\
\text { UNDERSTANDING DIVERGENCE ACROSS INDIAN } \\
\text { DISTRICTS }\end{array}$ \\
\hline 13.32 & Robertson, P.E. and Sin, A. & $\begin{array}{l}\text { MEASURING HARD POWER: CHINA'S ECONOMIC } \\
\text { GROWTH AND MILITARY CAPACITY }\end{array}$ \\
\hline 13.33 & Wu, Y. & $\begin{array}{l}\text { TRENDS AND PROSPECTS FOR THE RENEWABLE } \\
\text { ENERGY SECTOR IN THE EAS REGION }\end{array}$ \\
\hline 13.34 & $\begin{array}{l}\text { Yang, S., Zhao, D., Wu, Y. and } \\
\text { Fan, J. }\end{array}$ & $\begin{array}{l}\text { REGIONAL VARIATION IN CARBON EMISSION AND ITS } \\
\text { DRIVING FORCES IN CHINA: AN INDEX } \\
\text { DECOMPOSITION ANALYSIS }\end{array}$ \\
\hline
\end{tabular}




\section{ECONOMICS DISCUSSION PAPERS \\ 2014}

\begin{tabular}{|c|c|c|}
\hline $\begin{array}{l}\text { DP } \\
\text { NUMBER }\end{array}$ & AUTHORS & TITLE \\
\hline 14.01 & $\begin{array}{l}\text { Boediono, Vice President of the Republic } \\
\text { of Indonesia }\end{array}$ & $\begin{array}{l}\text { THE CHALLENGES OF POLICY MAKING IN A } \\
\text { YOUNG DEMOCRACY: THE CASE OF INDONESIA } \\
\text { (52ND SHANN MEMORIAL LECTURE, 2013) }\end{array}$ \\
\hline 14.02 & Metaxas, P.E. and Weber, E.J. & $\begin{array}{l}\text { AN AUSTRALIAN CONTRIBUTION TO } \\
\text { INTERNATIONAL TRADE THEORY: THE } \\
\text { DEPENDENT ECONOMY MODEL }\end{array}$ \\
\hline 14.03 & Fan, J., Zhao, D., Wu, Y. and Wei, J. & $\begin{array}{l}\text { CARBON PRICING AND ELECTRICITY MARKET } \\
\text { REFORMS IN CHINA }\end{array}$ \\
\hline 14.04 & McLure, M. & $\begin{array}{l}\text { A.C. PIGOU’S MEMBERSHIP OF THE } \\
\text { ‘CHAMBERLAIN-BRADBURY’ COMMITTEE. } \\
\text { PART I: THE HISTORICAL CONTEXT }\end{array}$ \\
\hline 14.05 & McLure, M. & $\begin{array}{l}\text { A.C. PIGOU’S MEMBERSHIP OF THE } \\
\text { ‘CHAMBERLAIN-BRADBURY’ COMMITTEE. } \\
\text { PART II: ‘TRANSITIONAL’AND ‘ONGOING’ ISSUES }\end{array}$ \\
\hline 14.06 & King, J.E. and McLure, M. & HISTORY OF THE CONCEPT OF VALUE \\
\hline 14.07 & Williams, A. & $\begin{array}{l}\text { A GLOBAL INDEX OF INFORMATION AND } \\
\text { POLITICAL TRANSPARENCY }\end{array}$ \\
\hline 14.08 & Knight, K. & $\begin{array}{l}\text { A.C. PIGOU'S THE THEORY OF UNEMPLOYMENT } \\
\text { AND ITS CORRIGENDA: THE LETTERS OF } \\
\text { MAURICE ALLEN, ARTHUR L. BOWLEY, RICHARD } \\
\text { KAHN AND DENNIS ROBERTSON }\end{array}$ \\
\hline 14.09 & Cheong, T.S. and Wu, Y. & $\begin{array}{l}\text { THE IMPACTS OF STRUCTURAL RANSFORMATION } \\
\text { AND INDUSTRIAL UPGRADING ON REGIONAL } \\
\text { INEQUALITY IN CHINA }\end{array}$ \\
\hline 14.10 & $\begin{array}{l}\text { Chowdhury, M.H., Dewan, M.N.A., } \\
\text { Quaddus, M., Naude, M. and } \\
\text { Siddique, A. }\end{array}$ & $\begin{array}{l}\text { GENDER EQUALITY AND SUSTAINABLE } \\
\text { DEVELOPMENT WITH A FOCUS ON THE COASTAL } \\
\text { FISHING COMMUNITY OF BANGLADESH }\end{array}$ \\
\hline 14.11 & Bon, J. & $\begin{array}{l}\text { UWA DISCUSSION PAPERS IN ECONOMICS: THE } \\
\text { FIRST } 750\end{array}$ \\
\hline 14.12 & Finlay, K. and Magnusson, L.M. & $\begin{array}{l}\text { BOOTSTRAP METHODS FOR INFERENCE WITH } \\
\text { CLUSTER-SAMPLE IV MODELS }\end{array}$ \\
\hline 14.13 & Chen, A. and Groenewold, N. & $\begin{array}{l}\text { THE EFFECTS OF MACROECONOMIC SHOCKS ON } \\
\text { THE DISTRIBUTION OF PROVINCIAL OUTPUT IN } \\
\text { CHINA: ESTIMATES FROM A RESTRICTED VAR } \\
\text { MODEL }\end{array}$ \\
\hline 14.14 & Hartley, P.R. and Medlock III, K.B. & $\begin{array}{l}\text { THE VALLEY OF DEATH FOR NEW ENERGY } \\
\text { TECHNOLOGIES }\end{array}$ \\
\hline 14.15 & $\begin{array}{l}\text { Hartley, P.R., Medlock III, K.B., } \\
\text { Temzelides, T. and Zhang, X. }\end{array}$ & $\begin{array}{l}\text { LOCAL EMPLOYMENT IMPACT FROM COMPETING } \\
\text { ENERGY SOURCES: SHALE GAS VERSUS WIND } \\
\text { GENERATION IN TEXAS }\end{array}$ \\
\hline 14.16 & Tyers, R. and Zhang, Y. & $\begin{array}{l}\text { SHORT RUN EFFECTS OF THE ECONOMIC REFORM } \\
\text { AGENDA }\end{array}$ \\
\hline 14.17 & Clements, K.W., Si, J. and Simpson, T. & UNDERSTANDING NEW RESOURCE PROJECTS \\
\hline 14.18 & Tyers, R. & $\begin{array}{l}\text { SERVICE OLIGOPOLIES AND AUSTRALIA’S } \\
\text { ECONOMY-WIDE PERFORMANCE }\end{array}$ \\
\hline 14.19 & Tyers, R. and Zhang, Y. & $\begin{array}{l}\text { REAL EXCHANGE RATE DETERMINATION AND } \\
\text { THE CHINA PUZZLE }\end{array}$ \\
\hline
\end{tabular}




\begin{tabular}{|c|c|c|}
\hline \multicolumn{3}{|c|}{$\begin{array}{l}\text { ECONOMICS DISCUSSION PAPERS } \\
\qquad 2014\end{array}$} \\
\hline $\begin{array}{l}\text { DP } \\
\text { NUMBER }\end{array}$ & AUTHORS & TITLE \\
\hline 14.20 & Ingram, S.R. & $\begin{array}{l}\text { COMMODITY PRICE CHANGES ARE } \\
\text { CONCENTRATED AT THE END OF THE CYCLE }\end{array}$ \\
\hline 14.21 & Cheong, T.S. and Wu, Y. & $\begin{array}{l}\text { CHINA'S INDUSTRIAL OUTPUT: A COUNTY-LEVEL } \\
\text { STUDY USING A NEW FRAMEWORK OF } \\
\text { DISTRIBUTION DYNAMICS ANALYSIS }\end{array}$ \\
\hline 14.22 & $\begin{array}{l}\text { Siddique, M.A.B., Wibowo, H. and } \\
\text { Wu, Y. }\end{array}$ & $\begin{array}{l}\text { FISCAL DECENTRALISATION AND INEQUALITY IN } \\
\text { INDONESIA: 1999-2008 }\end{array}$ \\
\hline 14.23 & Tyers, R. & $\begin{array}{l}\text { ASYMMETRY IN BOOM-BUST SHOCKS: } \\
\text { AUSTRALIAN PERFORMANCE WITH OLIGOPOLY }\end{array}$ \\
\hline 14.24 & Arora, V., Tyers, R. and Zhang, Y. & $\begin{array}{l}\text { RECONSTRUCTING THE SAVINGS GLUT: THE } \\
\text { GLOBAL IMPLICATIONS OF ASIAN EXCESS } \\
\text { SAVING }\end{array}$ \\
\hline 14.25 & Tyers, R. & $\begin{array}{l}\text { INTERNATIONAL EFFECTS OF CHINA'S RISE AND } \\
\text { TRANSITION: NEOCLASSICAL AND KEYNESIAN } \\
\text { PERSPECTIVES }\end{array}$ \\
\hline 14.26 & Milton, S. and Siddique, M.A.B. & $\begin{array}{l}\text { TRADE CREATION AND DIVERSION UNDER THE } \\
\text { THAILAND-AUSTRALIA FREE TRADE AGREEMENT } \\
\text { (TAFTA) }\end{array}$ \\
\hline 14.27 & Clements, K.W. and Li, L. & VALUING RESOURCE INVESTMENTS \\
\hline 14.28 & Tyers, R. & $\begin{array}{l}\text { PESSIMISM SHOCKS IN A MODEL OF GLOBAL } \\
\text { MACROECONOMIC INTERDEPENDENCE }\end{array}$ \\
\hline 14.29 & Iqbal, K. and Siddique, M.A.B. & $\begin{array}{l}\text { THE IMPACT OF CLIMATE CHANGE ON } \\
\text { AGRICULTURAL PRODUCTIVITY: EVIDENCE } \\
\text { FROM PANEL DATA OF BANGLADESH }\end{array}$ \\
\hline 14.30 & Ezzati, P. & $\begin{array}{l}\text { MONETARY POLICY RESPONSES TO FOREIGN } \\
\text { FINANCIAL MARKET SHOCKS: APPLICATION OF A } \\
\text { MODIFIED OPEN-ECONOMY TAYLOR RULE }\end{array}$ \\
\hline 14.31 & Tang, S.H.K. and Leung, C.K.Y. & $\begin{array}{l}\text { THE DEEP HISTORICAL ROOTS OF } \\
\text { MACROECONOMIC VOLATILITY }\end{array}$ \\
\hline 14.32 & Arthmar, R. and McLure, M. & $\begin{array}{l}\text { PIGOU, DEL VECCHIO AND SRAFFA: THE } 1955 \\
\text { INTERNATIONAL ‘ANTONIO FELTRINELLI’ PRIZE } \\
\text { FOR THE ECONOMIC AND SOCIAL SCIENCES }\end{array}$ \\
\hline 14.33 & McLure, M. & $\begin{array}{l}\text { A-HISTORIAL ECONOMIC DYNAMICS: A BOOK } \\
\text { REVIEW }\end{array}$ \\
\hline 14.34 & Clements, K.W. and Gao, G. & $\begin{array}{l}\text { THE ROTTERDAM DEMAND MODEL HALF A } \\
\text { CENTURY ON }\end{array}$ \\
\hline
\end{tabular}




\begin{tabular}{|c|c|c|}
\hline \multicolumn{3}{|c|}{$\begin{array}{l}\text { ECONOMICS DISCUSSION PAPERS } \\
2015\end{array}$} \\
\hline $\begin{array}{l}\text { DP } \\
\text { NUMBER }\end{array}$ & AUTHORS & TITLE \\
\hline 15.01 & Robertson, P.E. and Robitaille, M.C. & $\begin{array}{l}\text { THE GRAVITY OF RESOURCES AND THE TYRANNY OF } \\
\text { DISTANCE }\end{array}$ \\
\hline 15.02 & Tyers, R. & $\begin{array}{l}\text { FINANCIAL INTEGRATION AND CHINA’S GLOBAL } \\
\text { IMPACT }\end{array}$ \\
\hline 15.03 & Clements, K.W. and Si, J. & $\begin{array}{l}\text { MORE ON THE PRICE-RESPONSIVENESS OF FOOD } \\
\text { CONSUMPTION }\end{array}$ \\
\hline 15.04 & Tang, S.H.K. & $\begin{array}{l}\text { PARENTS, MIGRANT DOMESTIC WORKERS, AND } \\
\text { CHILDREN'S SPEAKING OF A SECOND LANGUAGE: } \\
\text { EVIDENCE FROM HONG KONG }\end{array}$ \\
\hline 15.05 & Tyers, R. & $\begin{array}{l}\text { CHINA AND GLOBAL MACROECONOMIC } \\
\text { INTERDEPENDENCE }\end{array}$ \\
\hline 15.06 & $\begin{array}{l}\text { Fan, J., Wu, Y., Guo, X., Zhao, D. } \\
\text { and Marinova, D. }\end{array}$ & $\begin{array}{l}\text { REGIONAL DISPARITY OF EMBEDDED CARBON } \\
\text { FOOTPRINT AND ITS SOURCES IN CHINA: A } \\
\text { CONSUMPTION PERSPECTIVE }\end{array}$ \\
\hline 15.07 & $\begin{array}{l}\text { Fan, J., Wang, S., Wu, Y., Li, J. and } \\
\text { Zhao, D. }\end{array}$ & $\begin{array}{l}\text { BUFFER EFFECT AND PRICE EFFECT OF A PERSONAL } \\
\text { CARBON TRADING SCHEME }\end{array}$ \\
\hline 15.08 & Neill, K. & $\begin{array}{l}\text { WESTERN AUSTRALIA'S DOMESTIC GAS } \\
\text { RESERVATION POLICY THE ELEMENTAL ECONOMICS }\end{array}$ \\
\hline 15.09 & Collins, J., Baer, B. and Weber, E.J. & THE EVOLUTIONARY FOUNDATIONS OF ECONOMICS \\
\hline 15.10 & $\begin{array}{l}\text { Siddique, A., Selvanathan, E. A. and } \\
\text { Selvanathan, S. }\end{array}$ & $\begin{array}{l}\text { THE IMPACT OF EXTERNAL DEBT ON ECONOMIC } \\
\text { GROWTH: EMPIRICAL EVIDENCE FROM HIGHLY } \\
\text { INDEBTED POOR COUNTRIES }\end{array}$ \\
\hline 15.11 & $\mathrm{Wu}, \mathrm{Y}$. & $\begin{array}{l}\text { LOCAL GOVERNMENT DEBT AND ECONOMIC } \\
\text { GROWTH IN CHINA }\end{array}$ \\
\hline 15.12 & Tyers, R. and Bain, I. & $\begin{array}{l}\text { THE GLOBAL ECONOMIC IMPLICATIONS OF FREER } \\
\text { SKILLED MIGRATION }\end{array}$ \\
\hline 15.13 & Chen, A. and Groenewold, N. & $\begin{array}{l}\text { AN INCREASE IN THE RETIREMENT AGE IN CHINA: } \\
\text { THE REGIONAL ECONOMIC EFFECTS }\end{array}$ \\
\hline 15.14 & Knight, K. & PIGOU, A LOYAL MARSHALLIAN? \\
\hline 15.15 & Kristoffersen, I. & $\begin{array}{l}\text { THE AGE-HAPPINESS PUZZLE: THE ROLE OF } \\
\text { ECONOMIC CIRCUMSTANCES AND FINANCIAL } \\
\text { SATISFACTION }\end{array}$ \\
\hline 15.16 & Azwar, P. and Tyers, R. & INDONESIAN MACRO POLICY THROUGH TWO CRISES \\
\hline 15.17 & Asano, A. and Tyers, R. & $\begin{array}{l}\text { THIRD ARROW REFORMS AND JAPAN'S ECONOMIC } \\
\text { PERFORMANCE }\end{array}$ \\
\hline 15.18 & Arthmar, R. and McLure, M. & $\begin{array}{l}\text { ON BRITAIN’S RETURN TO THE GOLD STANDARD: } \\
\text { WAS THERE A ‘PIGOU-MCKENNA SCHOOL’? }\end{array}$ \\
\hline 15.19 & $\begin{array}{l}\text { Fan, J., Li, Y., Wu, Y., Wang, S., and } \\
\text { Zhao, D. }\end{array}$ & $\begin{array}{l}\text { ALLOWANCE TRADING AND ENERGY CONSUMPTION } \\
\text { UNDER A PERSONAL CARBON TRADING SCHEME: A } \\
\text { DYNAMIC PROGRAMMING APPROACH }\end{array}$ \\
\hline 15.20 & Shehabi, M. & $\begin{array}{l}\text { AN EXTRAORDINARY RECOVERY: KUWAIT } \\
\text { FOLLOWING THE GULF WAR }\end{array}$ \\
\hline
\end{tabular}

